\title{
Mast cell chemotaxis - chemoattractants and signaling pathways
}

\section{Ivana Halova, Lubica Draberova and Petr Draber*}

Department of Signal Transduction, Institute of Molecular Genetics, Academy of Sciences of the Czech Republic, Prague, Czech Republic

\section{Edited by:}

Ulrich Blank, Université Paris-Diderot Paris 7, France

\section{Reviewed by:}

Axel Lorentz, University of

Hohenheim, Germany

Jaroslaw Dastych, Institute of

Medical Biology of the Polish

Academy of Sciences, Poland

\section{*Correspondence:}

Petr Draber, Department of Signal

Transduction, Institute of Molecular Genetics, Academy of Sciences of the Czech Republic, Videnska 1083, Prague 4 CZ142 20, Czech Republic. e-mail:draberpe@img.cas.cz
Migration of mast cells is essential for their recruitment within target tissues where they play an important role in innate and adaptive immune responses. These processes rely on the ability of mast cells to recognize appropriate chemotactic stimuli and react to them by a chemotactic response. Another level of intercellular communication is attained by production of chemoattractants by activated mast cells, which results in accumulation of mast cells and other hematopoietic cells at the sites of inflammation. Mast cells express numerous surface receptors for various ligands with properties of potent chemoattractants. They include the stem cell factor (SCF) recognized by c-Kit, antigen, which binds to immunoglobulin $\mathrm{E}$ (IgE) anchored to the high affinity IgE receptor (FcERI), highly cytokinergic $(\mathrm{HC})$ IgE recognized by Fc\&RI, lipid mediator sphingosine-1-phosphate (S1P), which binds to $\mathrm{G}$ protein-coupled receptors (GPCRs). Other large groups of chemoattractants are eicosanoids [prostaglandin $E_{2}$ and $D_{2}$, leukotriene $(L T) B_{4}$, LTD 4 , and $L T C_{4}$, and others] and chemokines (CC, CXC, $\mathrm{C}$, and $\mathrm{CX} 3 \mathrm{C}$ ), which also bind to various GPCRs. Further noteworthy chemoattractants are isoforms of transforming growth factor (TGF) $\beta 1-3$, which are sensitively recognized by TGF- $\beta$ serine/threonine type I and II $\beta$ receptors, adenosine, $\mathrm{C} 1 \mathrm{q}, \mathrm{C} 3 \mathrm{a}$, and $\mathrm{C} 5 \mathrm{a}$ components of the complement, 5-hydroxytryptamine, neuroendocrine peptide catestatin, tumor necrosis factor- $\alpha$, and others. Here we discuss the major types of chemoattractants recognized by mast cells, their target receptors, as well as signaling pathways they utilize. We also briefly deal with methods used for studies of mast cell chemotaxis and with ways of how these studies profited from the results obtained in other cellular systems.

Keywords: mast cell, IgE receptor, plasma membrane, chemoattractant, chemotaxis, cell migration, signal transduction

\section{INTRODUCTION}

Mast cells are derived from progenitors that are released from bone marrow into circulation, and subsequently migrate into peripheral tissues. Within this time period they undergo differentiation and maturation. These processes are controlled by chemotactic agents and growth factors present in circulation and at sites of mast cell residency. In peripheral tissues the progenitors differentiate into one of two possible classes of mature mast cells, connective tissue, or mucosal mast cells. They differ in many properties, including the mediators they produce and secrete. Connective tissue mast cells are found in the skin, around blood vessels, and in peritoneal cavity, whereas mucosal mast cells localize in the linings of the lung and intestine. Differentiation of mast cells into these two classes is directed by various growth factors and chemoattractants produced by various cell types present in the surrounding tissue environment. Accumulation of mast cells within tissues is observed in many pathophysiological conditions. Mature mast cells infiltrate the sites of inflammation associated with chronic atopic disease or during helminthic or bacterial infection. Directed migration of mature mast cells or their progenitors might be one of the key mechanisms responsible for local accumulation of these cells. This recruitment depends on the presence of chemical compounds named chemoattractants, which are produced locally at sites of inflammation by various cell types.
Importantly, mast cells themselves can produce and secrete various chemoattractants including adenosine, sphingosine-1-phosphate (S1P), and leukotriene (LT) $\mathrm{B}_{4}$, and attract in this way other mast cells and/or their progenitors by the autocrine/paracrine fashion. Various chemoattractants and the corresponding receptors are involved in mast cell migration and they can in part share the downstream signaling pathways. Others use pathways that are unique for each particular chemoattractant/receptor. This divergence and convergence of signaling pathways is important for proper cooperation among receptors triggered with various chemoattractants, and contributes to specific behavior of mast cells. There are two main types of migration, chemokinesis and chemotaxis. Whereas chemokinesis is a random, non-vectorial moiety, chemotaxis is directional migration toward higher concentrations of a chemoattractant. This review deals with major types of mast cell chemoattractants and their production, as well as with signaling pathways they utilize. It starts with a brief description of methods used for studies of mast cell chemotaxis.

\section{METHODS USED FOR STUDIES OF MAST CELL CHEMOTAXIS}

Numerous methods have been developed for studies on mast cell migration, chemotaxis, and activity of various cytokines. Although there are large numbers of mast cells in an adult organism, they cannot be easily isolated because they are scattered throughout 
various parts of the body. In most of the studies, mast cells of mouse, rat, and human origin have been used. In mice, bone marrow derived mast cells (BMMCs) are often studied. These cells can be obtained by culturing bone marrow progenitors in the presence of interleukin (IL)-3 and SCF (Razin et al., 1981; Tsai et al., 1991). In rat, mast cells are often isolated in mature stage from peritoneal cavity (Cooper and Stanworth, 1976; Poole and Zetter, 1983; Gruber et al., 1994; Brzezińska-Błaszczyk et al., 2007). Human mast cells are usually obtained by culturing mast cell progenitors from various tissues in the presence of SCF, IL-6, and IL-10. Progenitors from skin give rise to skin mast cells (SMCs; de Paulis et al., 2001); those from intestine produce intestine mast cells (IMCs; Fox et al., 1985; Feuser et al., 2012); progenitors from lungs, cord blood, or peripheral blood differentiate, respectively into lung mast cells (LMCs; Romagnani et al., 1999; Brightling et al., 2005b), cord blood mast cells (CBMCs; Nilsson et al., 1994; Ochi et al., 1999; Oskeritzian et al., 2008), or peripheral blood mast cells (PBMCs; Saito et al., 2006; Aung et al., 2011). Human BMMCs have been also used in some studies (Brightling et al., 2005b). Chemotaxis was also studied using mast cell lines, such as rat basophilic leukemia (RBL) cells, clone 2H3 (Jolly et al., 2004, 2005; Toda et al., 2004), human mast cell line (HMC-1; Nilsson et al., 2000; Brightling et al., 2005b; Lundeen et al., 2006; and others), or human lymphoma cell line LAD-2 (Oskeritzian et al., 2008).

Experiments with various mast cell types have shown that the expression pattern of surface receptors for chemoattractants depends on origin of the cells and their maturation (Ochi et al., 1999; Weller et al., 2005; Collington et al., 2010a). Results on the effect of chemoattractants also depend on the method used. The methods can be divided on methods in vivo and in vitro.

\section{METHODS IN VIVO}

Methods in vivo usually evaluate the accumulation of mast cells at sites of chemoattractant injection. Chemoattractants are usually injected intradermally (i.d.) and mice are sacrificed at various time intervals after injection. Skin at the site of injection is then removed, fixed, stained with toluidine blue, and examined by microscopy to determine the number of mast cells (Matsui and Nishikawa, 2005; Kitaura et al., 2005b).

Alternatively, mast cell progenitors or mature mast cells are isolated and cultured up to definite developmental stages. The cells are then labeled with various trackers (fluorescent or radioactive) followed by intravenous (i.v.) tail vein injection some time before i.d. injection of chemoattractant into dorsal skin. The mice are then sacrificed and skin biopsies are evaluated depending on the tracker used (Weller et al., 2005, 2007; Boehme et al., 2009; Collington et al., 2010a). In such experiments, mast cells obtained from mice deficient in specific genes could be injected into mice deficient in mast cells to determine the role of selected molecules in chemotaxis. Exposure of the cells to antibodies specific for selected surface receptors can be used for determination of the possible role of the receptors in mast cell chemotaxis (Brightling et al., 2005b; Kitaura et al., 2005b; Kuehn et al., 2010).

\section{METHODS IN VITRO}

Most of the assays on chemotaxis in vitro utilized various modifications of Boyden's chamber where cells migrate toward chemoattractants through pores (usually 5 or $8 \mu \mathrm{m}$ ) of polycarbonate membrane. Common is the use of Transwell permeable supports placed into 24-well polystyrene plates. Mast cells are introduced into the upper chamber, which is placed into a well containing chemotaxis buffer supplemented with the chemoattractant at selected concentration. The plates are kept for several hours (usually 2-8) at $37^{\circ} \mathrm{C}$ in $\mathrm{CO}_{2}$ incubator. The cells migrate toward chemoattractant through the pores of the membrane and accumulate at the bottom of the well. The number of cells is counted with a hemocytometer or flow cytometer. Alternatively, the cells are labeled with fluorescent dye and quantified by determining the florescence (Weller et al., 2005; Kuehn et al., 2010; Tủmová et al., 2010).

In some experiments the membranes were modified by coating with different substances, such as laminin or fibronectin, or epithelial cells (Nilsson et al., 1994; Oliveira and Lukacs, 2001; Kitaura et al., 2005b) and migration was evaluated by counting the number of migrated cells. Boyden chamber-based assays can also be used for identification of molecules or signaling pathways involved in chemotaxis. One major advantage of this system is its simplicity and ability to test many compounds at different concentrations simultaneously, to examine the role of pharmacological inhibitors on chemotaxis, and also to analyze chemokinesis, which reflects migration independent on the presence of chemoattractants. However, this method has its limitation. One of them is that only sharp chemotactic gradient can be generated and it is impossible to assess the speed of migration of individual cells or directions of movement of the cells.

Methods analyzing individual migrating cells in real time are often based on microscopic technique and on recording the cell movement in selected time intervals. These real time methods could be combined with different modifications of under-agarose or "tunnel" assays, which are used for studying multiple chemotactic gradients, shape and speed of migrating cells, or assessing the roles of selected adhesion molecules (Poole and Zetter, 1983; Heit et al., 2002). In the under-agarose method, tissue culture dishes are precoated with a blocking agent such as BSA, calf serum, or collagen, and then overlaid by agarose. After agarose solidifies, three holes of $3 \mathrm{~mm}$ in diameter and $3 \mathrm{~mm}$ apart are punched in the gel. Mast cells are dispensed to the middle hole and chemoattractants to the others. The migration is observed under microscope in real time or the migrated cells can be stained at the end of the assay and quantified. This method can also be modified by using specific inhibitors, activators, or antibodies (Heit et al., 2002). The obtained images can by analyzed by cell tracking plugins: http://rsb.info.nih.gov/ij/; http://www.imagescience.org/ meijering/software/mtrackj; or http://www.ibidi.com/applications lap_chemo.html

Horizontal chemotactic assays in KK chambers (Kanegasaki et al., 2003) were used for studying the migration of BMMCs toward antigen. KK chambers consist of etched silicon substrate and a flat glass plate that forms compartment with a $5-\mu \mathrm{m}$-deep microchannel. A charge-coupled device camera is used to record the migrating cells (Kanegasaki et al., 2003; Sawada et al., 2005). The main advantage of recording the cells in real time is that investigators can observe not only individual migrating cells but also their dynamic behavior during the process. This method 
in combination with cells carrying fluorescently tagged proteins could also be useful for studying the involvement of these proteins in chemotaxis.

\section{MAST CELL CHEMOATTRACTANTS}

Numerous chemoattractants have been described capable of inducing chemotaxis in mast cells. Some of them, and corresponding receptors, are summarized in Table $\mathbf{1}$ and described below.

\section{STEM CELL FACTOR}

Stem cell factor, also known as steel factor or c-Kit-ligand, is a hematopoietic growth factor that promotes survival, proliferation, and differentiation of hematopoietic cells (for review see Roskoski, 2005; Okayama and Kawakami, 2006; Jensen et al., 2008). It is produced in both soluble and membrane-bound form by alternative splicing of the same RNA transcript, and is a major chemotactic factor for mast cells and their progenitors (Chabot et al., 1988; Meininger et al., 1992; Nilsson et al., 1994, 1998). SCF is produced by a wide variety of cells including fibroblasts and endothelial cells. Its receptor, c-Kit, is a type III tyrosine kinase broadly expressed on mature mast cells and eosinophils. SCF promotes recruitment of mast cell progenitors into tissues, as well as their local maturation and activation. It also promotes eosinophil survival, maturation, and functional activation (Chabot et al., 1988; Okayama and Kawakami, 2006). Binding of SCF to the cell induces dimerization of the receptors, followed by their transphosphorylation at tyrosine residues (Tyr568 and Tyr570) and consequently formation of docking sites for the Src-homology $(\mathrm{SH})$ 2-containing signal transduction molecules. It has been demonstrated that Src-family protein tyrosine kinases Lyn and Fyn are phosphorylated and activated after c-Kit triggering (Linnekin et al., 1997; Timokhina et al., 1998) and that the event leads to further propagation of the signal (Figure 1).

There are several signaling pathways resulting in degranulation, survival, and migration of mast cells. An important pathway depends on PI3K and subsequent phosphorylation of Akt, and is therefore related to c-Kit-dependent mast cell survival. Fyn-dependent axis leads to the phosphorylation of Gab2, mediates through small GTPase Rac the cytoskeleton reorganization and influences mast cell migration (Linnekin et al., 1997; Timokhina et al., 1998; Samayawardhena et al., 2006; Samayawardhena et al., 2007). Studies with different murine c-Kit mutants showed the importance of Y719 and Y567 for c-Kit-mediated chemotaxis. Phosphorylated Y719 recruited PI3K and mediated thus an enhanced $\mathrm{Ca}^{2+}$ signal, which was found to be critical for chemotaxis. In contrast, phosphorylated Y567 recruited Lyn or Fyn resulting in activation of $\mathrm{p} 38$ pathway, also important for chemotaxis (Ueda et al., 2002; Samayawardhena et al., 2006). Decreased migration toward SCF was observed in cells with a defect in expression of protein tyrosine phosphatase (PTP $\alpha$; Samayawardhena and Pallen, 2008). When compared to wild-type cells, the PTP $\alpha$-deficient cells exhibited reduced Fyn kinase activity causing defects in phosphorylation of tyrosines 567/569 and 719 of c-Kit. PI3K and Akt activation was unaffected in PTP $\alpha^{-1-}$ BMMCs. Thus PTP $\alpha$ is required for SCF-induced migration which employs the Fyn/Gab2/Shp2/Vav/PAK/Rac/JNK signaling axis (Samayawardhena and Pallen, 2008). Chemotaxis is also positively regulated by Fes kinase because migration of $\mathrm{Fes}^{-1-}$ mast cells toward SCF was decreased (Smith et al., 2010).

Studies with macrophages showed regulation of PI3Kdependent migration by negative feedback of phosphatase and tensin homolog (PTEN; Papakonstanti et al., 2007). Knock-down of PTEN in mast cells led to increased basal level of PIP3 and constitutive activation of Akt, p38, and JNK, resulting in enhanced survival and increased production of several cytokines, including IL-3, IL-6, and tumor necrosis factor (TNF)- $\alpha$ in antigen-activated cells (Furumoto et al., 2006). It was also shown that PTEN deficiency enhanced the number of mast cells in different tissues. This suggested that PTEN could play a regulatory role in mast cell chemotaxis (Furumoto et al., 2006). Experiments with neutrophils showed that SHIP1, other phosphatase regulating amount of PIP3, was even more important for migration than PTEN (Nishio et al., 2007; Subramanian et al., 2007). Interestingly, SHIP1 knock-out mice exhibited mast cell hyperplasia in several tissues (Haddon et al., 2009), which could be also consequence of increased chemotaxis. Elucidation of the role of these two phosphatases in mast cell chemotaxis requires further studies.

Mammalian target of rapamycin complexes (mTORCs) were found to play important roles in chemotaxis of several cell models such as neutrophils (Charest et al., 2010; Liu et al., 2010) and Dictyostelium (Sasaki and Firtel, 2006; Takeda et al., 2007; Liu and Parent, 2011). mTORC1 is activated in PI3K-dependent manner and its inhibition by rapamycin depressed the SCF-mediated migration (Kim et al., 2008a,b). mTORC2 appears to play an important role in $\mathrm{PGE}_{2}$-mediated chemotaxis (Kuehn et al., 2011b; see below) but its role in SCF- or antigen-mediated chemotaxis is to be defined.

In this connection, it should be mentioned that patients with c-Kit mutation D816V exhibit constitutive activation of c-Kit and accumulation of mast cells derived from $\mathrm{CD} 34^{+} \mathrm{CD} 117^{+}$ mast cell precursors. Experiments with such precursors obtained from patients with mastocytosis showed that only less than $10 \%$ prechemotactic sample had D $816 \mathrm{~V}$ mutation, whereas as many as $40-80 \%$ of migrated cells showed the mutation (Taylor et al., 2001). The results indicate that D816V mutation in c-Kit enhances the SCF-dependent chemotaxis and could promote in this way the mastocytosis.

\section{ANTIGEN}

FcERI is a tetrameric receptor consisting of an immunoglobulin E (IgE)-binding $\alpha$ chain, $\beta$ chain, and two $\gamma$ chains. Binding of IgE to $\alpha$ chain and subsequent crosslinking of the receptor by the multivalent antigen leads to phosphorylation of immunoreceptor tyrosine-based activation motifs (ITAMs) in the cytoplasmic tails of the FceRI $\beta$ and $\gamma$ chains by Lyn kinase (Figure 2; Eiseman and Bolen, 1992; Yamashita et al., 1994). Phosphorylated ITAMs are able to bind a broad variety of positive as well as negative regulators of immunoreceptor signaling. The most important propagator of the positive signal is a protein tyrosine kinase Syk, which after binding to phosphorylated tyrosines of ITAM assumes an active conformation facilitating its phosphorylation by Lyn and further increase in enzymatic activity. Consequently, Syk phosphorylates a number of its downstream targets critical for further 
Table 1 | Summary table of different mast cell chemoattractants and their receptors.

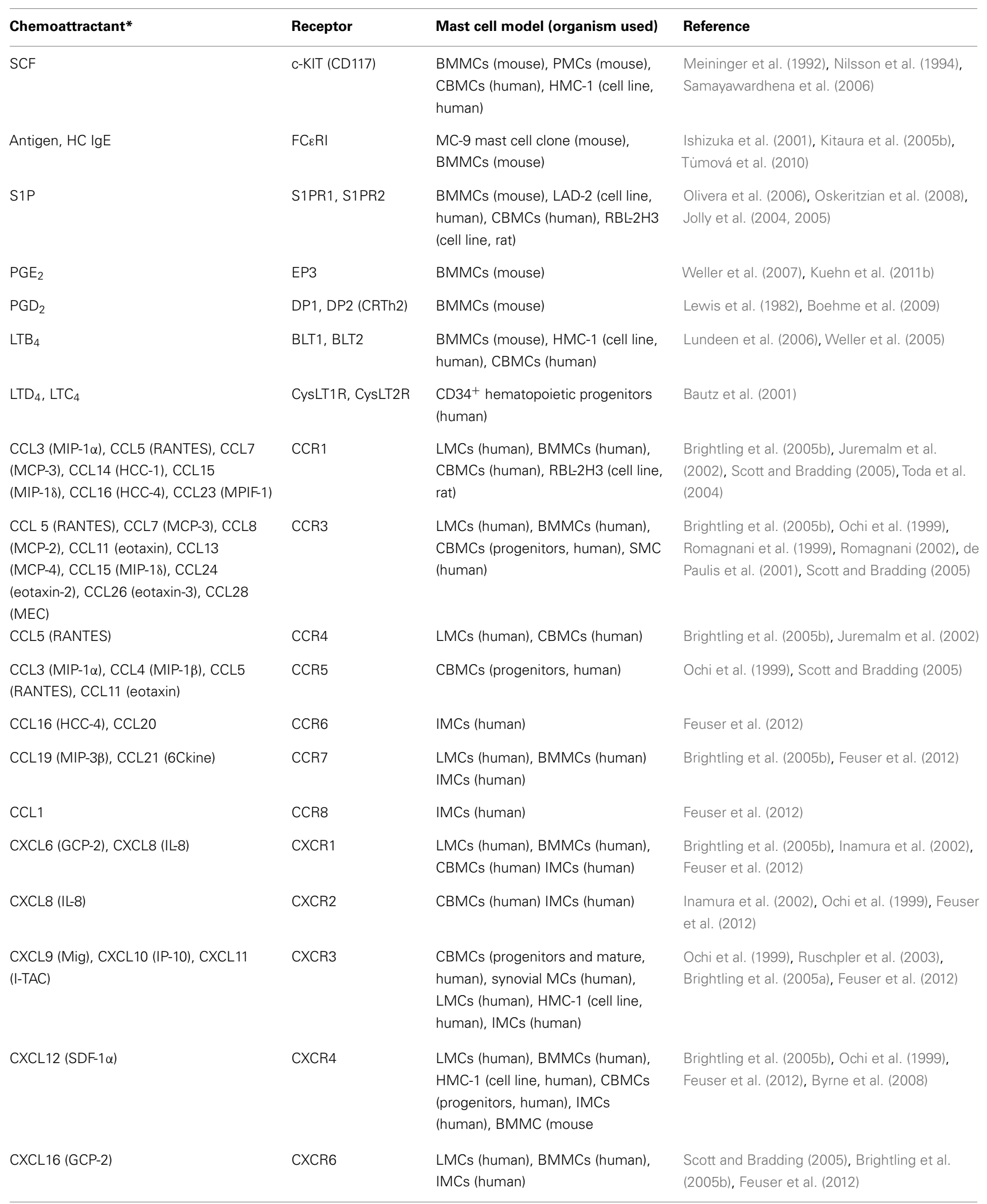


Table 1 | Continued

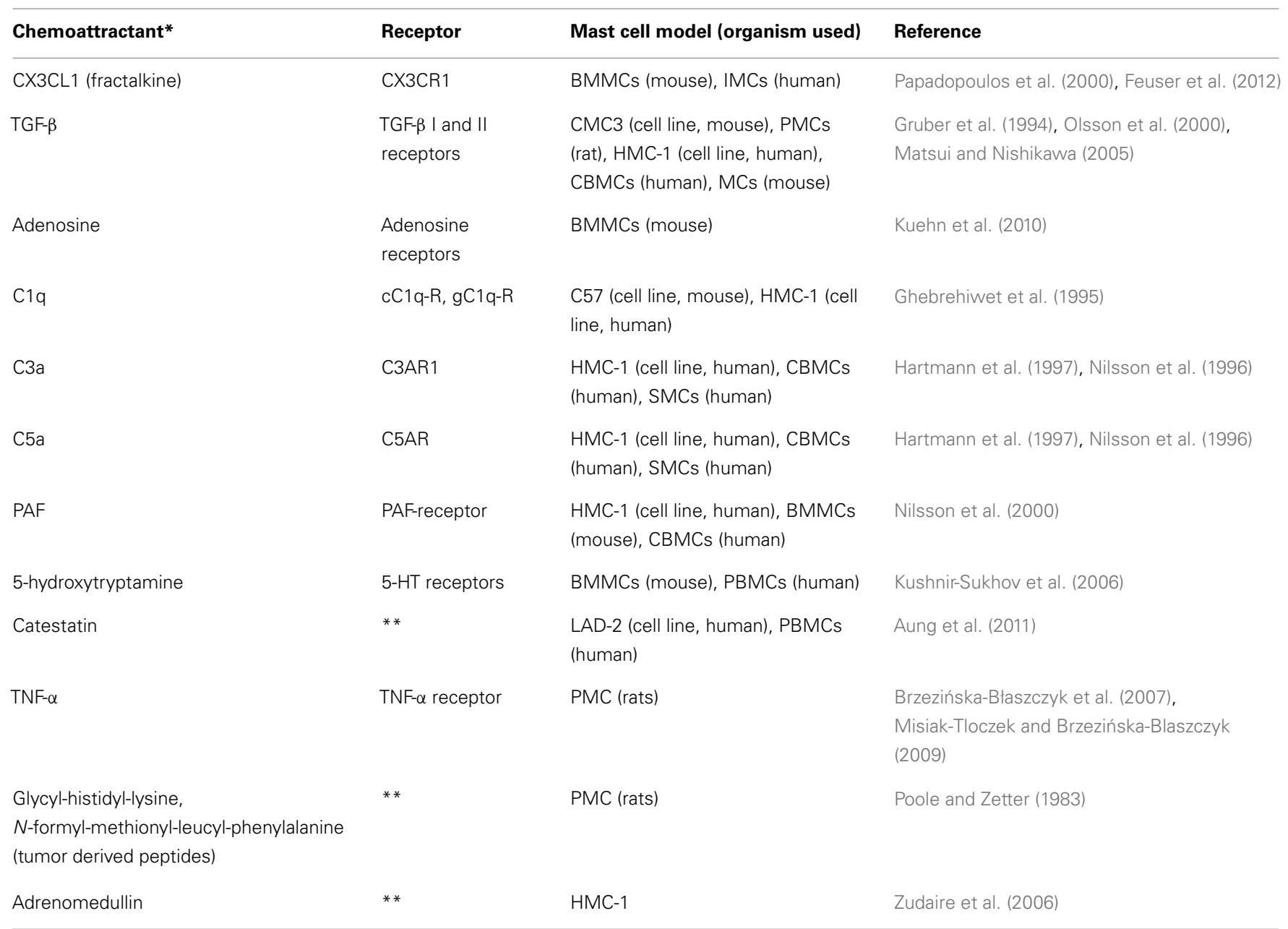

${ }^{*}$ For chemokines both new and old (in parenthesis) names are used in accord to chemokine nomenclature (Zlotnik and Yoshie, 2000).

* Specific receptors for the chemoattractants in mast cells have not yet been identified.

PMCs, peritoneal mast cells; RANTES, regulated upon activation, normal T-cell expressed and secreted.

propagation of the signal. These targets include transmembrane adaptor proteins, linker of activated T cells (LAT), and non-T cell activation linker (NTAL), as well as cytosolic adaptor proteins, such as growth factor receptor-bound protein 2 (Grb2), Grb2associated binder (Gab2), Grb2-related adaptor downstream of Shc (Gads), SH2 domain containing leukocyte protein of $76 \mathrm{kDa}$ (SLP-76) and others that often function in cooperation with various signaling proteins, forming multicomponent signaling units, signalosomes. Phosphorylated LAT associates directly or indirectly with numerous signaling molecules such as Grb2, phospholipase C $\gamma 1$ (PLC $\gamma 1$ ), guanine nucleotide exchange factor Vav, Cbl, SLP-76, and Gads (Gilliland et al., 1992; Buday et al., 1994; Sieh et al., 1994; Trub et al., 1997; Finco et al., 1998; Zhang et al., 1998; Liu et al., 1999; Ishiai et al., 2000). Phosphorylated NTAL interacts with a similar set of proteins except for PLC $\gamma 1$; this is an important difference explaining in part different roles of these two adaptors in mast cell signaling (Brdička et al., 2002; Janssen et al., 2003; Volná et al., 2004; Zhu et al., 2004; Draber et al., 2012). Further propagation of the signal activates PI3K, PLC $\gamma$, protein kinase $\mathrm{C}(\mathrm{PKC})$, and mitogen-activated protein kinase (MAPK).

Whereas the signaling pathways leading to degranulation and production of cytokines are relatively well understood, those involved in mast cell migration and chemotaxis are still vague. The first report on molecules involved in antigen-induced mast cell migration showed that $\mathrm{p} 38$ MAPK, MAPK-activated protein kinase 2 (MAPKAPK2) and Rho-associated kinase (ROCK) are involved (Ishizuka et al., 2001). Studies with BMMCs isolated from $\mathrm{NTAL}^{-1-}$ mice showed an important role of NTAL in antigeninduced migration. Absence of NTAL resulted in enhanced migration toward antigen, when compared to cells from wild-type mice; this negative regulatory role of NTAL is probably mediated by small GTPase RhoA and its kinase ROCK (Tủmová et al., 2010). RhoA regulates cortical filamentous (F)-actin disassembly, which is dependent on enhanced levels of free cytoplasmic calcium (Sullivan et al., 1999). Immunoreceptor activation leads to $\mathrm{Ca}^{2+}$ release from intracellular stores, which is followed by entry of external $\mathrm{Ca}^{2+}$ into the cells through store operated $\mathrm{Ca}^{2+}$ (SOC) channels. 


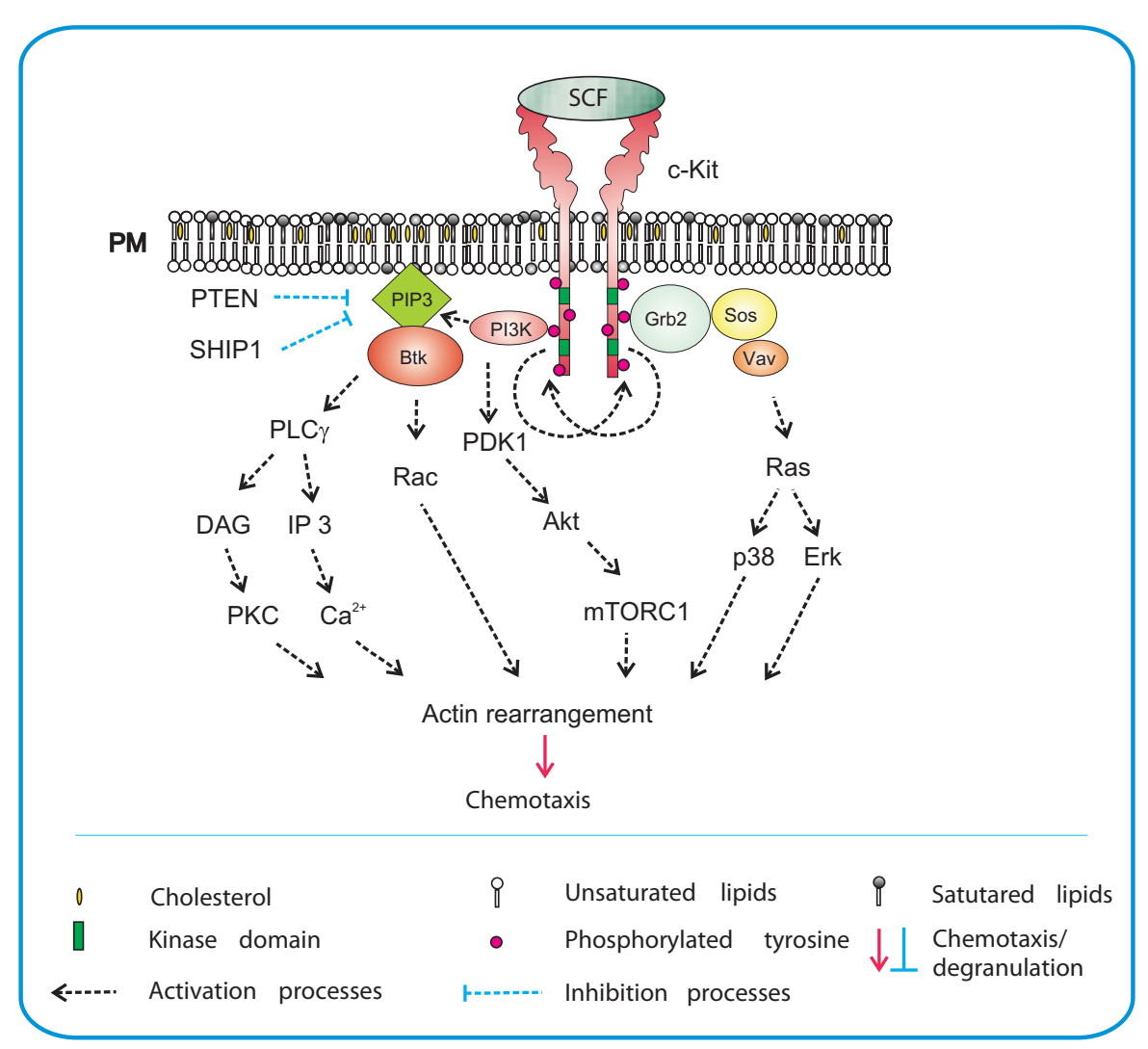

FIGURE 1 | SCF-mediated chemotaxis. Crosslinking of the plasma membrane (PM) anchored C-Kit by SCF results in dimerization of the receptor and its auto-transphosphorylation. This is followed by recruitment of $\mathrm{SH} 2$-domain containing proteins such as $\mathrm{PI} 3 \mathrm{~K}$ and Grb2 to c-Kit. Activated PI3K generates PIP3, a binding site for PH-domain containing protein Btk, and facilitates further propagation of the signal through activation of PLC $\gamma$. An increased activity of PLC $\gamma$ leads to production of DAG and IP3 and release of $\mathrm{Ca}^{2+}$. This is followed by actin rearrangements and chemotactic response. Production of PIP3 also leads to recruitment of phosphoinositide-dependent kinase (PDK)-1 and Akt to the plasma membrane and subsequent phosphorylation of Akt by PDK1. Akt directly phosphorylates the negative regulator of $\mathrm{mTORC1}$, inactivating thereby its inhibitory action. PIP3 levels are negatively regulated by phosphatases PTEN and SHIP1. Grb2 orchestrates activation of Ras by recruiting Ras and Rho family GEFs, Sos, and Vav. Through Ras, both p38 and Erk are activated and chemotaxis is also promoted in this way. Signaling molecules in bodies are those located at their sites of action and/or bound to the indicated target molecules; other signaling molecules are presented as plain text.
SOC influx depends on the presence of aggregated stromal interaction molecule 1 (STIM1; Dráber and Dráberová, 2005; Liou et al., 2005; Roos et al., 2005). The importance of SOC influx in immunoreceptor-directed chemotaxis was recently documented in studies with BMMCs deficient in STIM1. The defect resulted in inhibition of antigen-induced $\mathrm{Ca}^{2+}$ response, decreased formation of microtubule protrusions and impaired chemotactic response to antigen (Hájková et al., 2011). Experiments with pharmacological inhibitors showed that both Src and Syk kinases are important for antigen-mediated chemotaxis, whereas Tec kinases are not. These results were confirmed in studies using BMMCs derived from mice deficient in Syk, Btk, Lyn, Fyn, and Hck. Furthermore, the results demonstrated that Lyn is more important than Fyn, and that Hck has no fundamental role in this process. Studies with other inhibitors showed that PI3K, MAP kinases, p38, JNK, and PKC are all essential for antigen-mediated chemotaxis, unlike PKA or Rho-kinase (Kitaura et al., 2005b). The results with Rho-kinase and JNK are, however, in conflict with those presented by Ishizuka et al. (2001).
$\mathrm{PI} 3 \mathrm{~K}$ appears in several isoforms, and PI3K $\delta$ is the major regulator of chemotactic responses to antigen (Kuehn et al., 2010). In the cited study, the authors also showed the importance of Btk for antigen-mediated migration, which seems to disagree with other published data. Kitaura et al. (2005b) reported that antigenmediated chemotaxis operates in an autocrine-paracrine manner by releasing other chemoattractants such as monocyte chemoattractant protein (MCP)-1, $\mathrm{LTB}_{4}$, and adenosine, promoting chemotaxis toward antigen, and that Tec kinases are not involved in this process. These discrepancies could be attributable to different methods used for evaluation of chemotaxis: fibronectincoated polycarbonate membranes (Kitaura et al., 2005b), against uncoated membranes (Kuehn et al., 2010). It is known that fibronectin binds integrin and that the mechanisms of integrinmediated migration differ from those of integrin-independent movement (Narumiya and Watanabe, 2009; Renkawitz et al., 2009).

It has been reported that pretreatment of mast cells with SCF leads to inhibition of chemotaxis toward antigen (Sawada et al., 


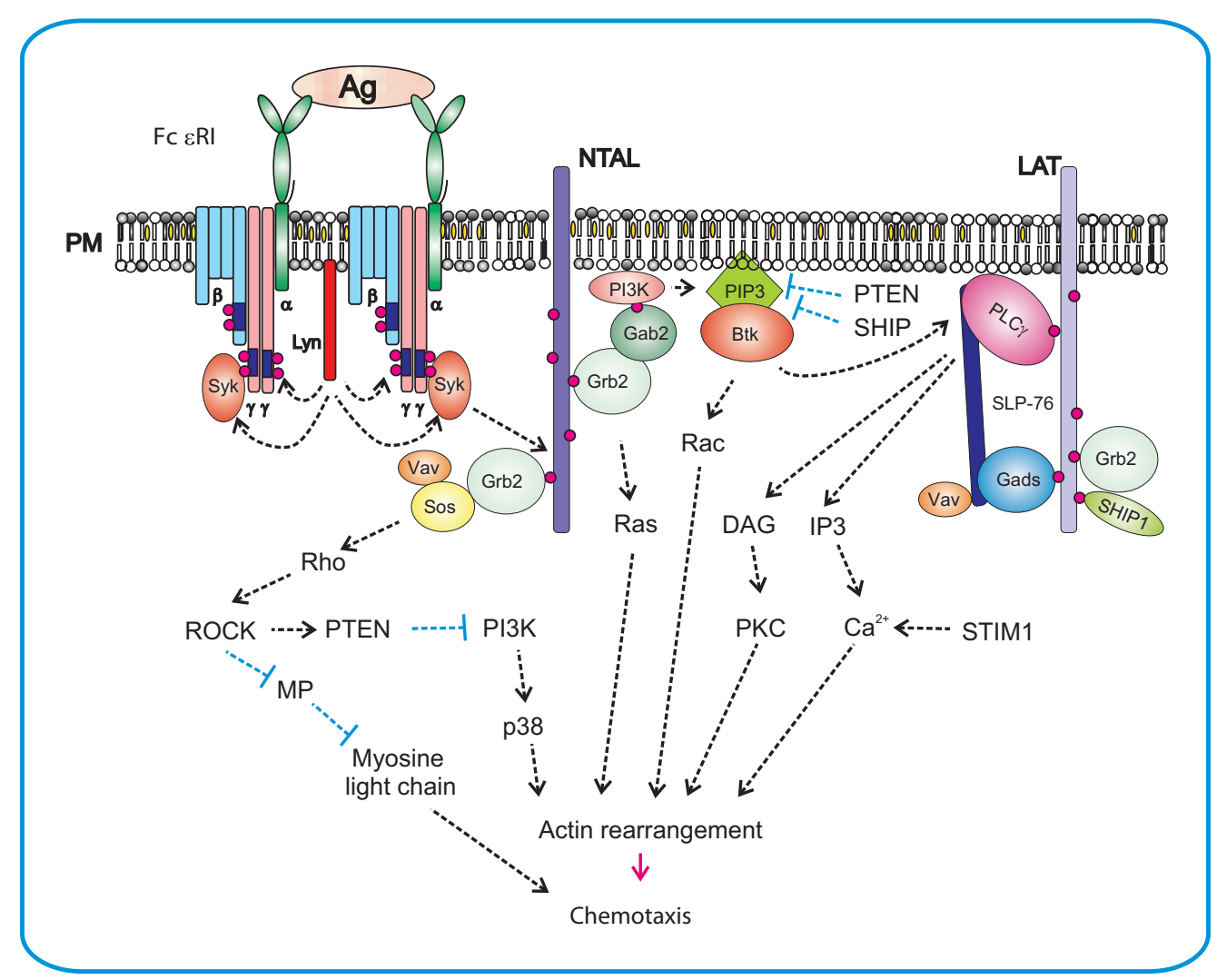

FIGURE 2 | Antigen-mediated chemotaxis. Aggregation of the FceRI by multivalent antigen leads to rapid Lyn kinase-mediated phosphorylation of tyrosine residues in ITAM motifs of $\mathrm{FcER}_{\mathrm{R}} \beta$ and $\gamma$ subunits. This is followed by anchoring of Syk to $\mathrm{F} c \varepsilon \mathrm{RI} \gamma$ through interaction of Syk SH2 domains with phosphorylated ITAMs. Syk then phosphorylates transmembrane adaptor proteins NTAL and LAT and creates binding sites for various $\mathrm{SH}$-containing proteins like Grb2. In this way it brings PI3K and Gab2 to the plasma membrane. Activated PI3K generates PIP3, a binding site for $\mathrm{PH}$-domain containing protein Btk. This leads to further propagation of the signal through activation of $\mathrm{PLC} \gamma$, resulting in $\mathrm{Ca}^{2+}$ release and actin rearrangement. Levels of free intracellular $\mathrm{Ca}^{2+}$ are positively regulated by aggregated STIM1. Another PI3K-dependent pathway contributes to activation of $\mathrm{p} 38$ and consequently to enhanced chemotactic response. Grb2 orchestrates activation of Ras by recruiting small GTPases Ras and Rho family GEFs, Sos, Vav, and other signaling molecules, resulting in actin rearrangement and chemotaxis. NTAL could play a negative regulatory role in chemotaxis through activation of Rho/ROCK pathway that is responsible for controlling the rear edge of the migrating cell. ROCK could also activate the PTEN phosphatase which inhibits activity of PI3K and in this way decreases the PIP3 levels.
2005). The authors suggested that in vivo locally produced SCF may have inhibitory effects on chemotaxis in mast cells with activated FceRI. This could foster the accumulation of mast cells at sites of inflammatory reactions. In contrast, chemotactic response of cells exposed simultaneously to antigen and SCF was higher than the response toward antigen alone, but lower than that induced by SCF alone (Túmová et al., 2010). However, different results were obtained in other experiments in which antigen and SCF added together caused a considerably higher chemotactic response than any of them alone (Kuehn et al., 2010). These discrepancies probably reflect differences in cells used, employed assays of migration, and/or other variables.

Antigen-mediated engagement of FceRI also has a distinct capacity to potentiate the action of $\mathrm{PGE}_{2}$, adenosine, and probably other chemoattractants (Zhong et al., 2003; Kuehn and Gilfillan, 2007; Kuehn et al., 2008, 2010). The observed crosstalk between signaling pathways that are induced by different activators might play an important role in mast cell physiology.

\section{HIGHLY CYTOKINERGIC IgE}

Mast cell activation and migration can also be induced by HC IgE in the absence of antigen (Kitaura et al., 2005a,b). The pathways and molecules involved in this process appear to be similar to those implicated in processes where IgE Fc\&RI complexes are aggregated by multivalent antigen.

\section{SPHINGOSINE-1-PHOSPHATE}

The lipid mediator S1P takes part in diverse biological processes, from vascular, and neural development to regulation of lymphocyte trafficking (Olivera, 2008; Rivera et al., 2008). S1P is produced by intracellular phosphorylation of sphingosine by two phylogenetically conserved sphingosine kinases SphK1 and SphK2 (Olivera and Spiegel, 2001). However, S1P can also be produced extracellularly by the secreted form of SphK1 (Ancellin et al., 2002). Intracellular levels of S1P are tightly regulated by a balance between its synthesis and degradation, occurring either reversibly by two specific S1P phosphatases or irreversibly by S1P lyase. It has 
been suggested that S1P lyase and S1P phosphatases can also influence the concentrations of S1P in the interstitium of lymph nodes and spleen, and probably other tissues as well, allowing the cells in those microenvironments to respond to local changes in S1P concentration (Schwab et al., 2005; Peest et al., 2008). Although SphK1 and SphK2 are highly homologous, they are not fully redundant functionally. SphK1 plays a positive role in cell growth and survival (Olivera et al., 1999), whereas overexpression of SphK2 induces cell death (Liu et al., 2003). On the other hand, studies employing genetically manipulated mice showed that knock-outs of either SphK1 or SphK2 separately were viable, had only slightly decreased S1P levels and exhibited no obvious phenotypes, whereas double SphK1/SphK2 knock-outs resulted in a complete loss of S1P and were embryonically lethal. It implies that these kinases have some redundant and overlapping functions (Mizugishi et al., 2005).

Activation of FceRI in mast cells correlated with increased activity of both SphKs, enhanced the formation of intracellular S1P, and promoted the export of S1P into extracellular space by specific ATP-binding cassette (ABC)-type transporters. After secretion, S1P can act in an autocrine/paracrine-dependent manner.
Although both SphK1 and SphK2 have been implicated in regulation of S1P production in mast cells, the details are still obscure. Loss of SphK2 in murine mast cells reduced S1P production and caused a substantial inhibition of FceRI-mediated degranulation as well as diminished production of IL-6, IL-13, and TNF- $\alpha$, primarily due to reductions in intracellular calcium levels and PKC activation. In contrast, SphK1-deficiency lowered the level of circulatory S1P in vivo and altered mast cell functions (Olivera et al., 2007). SphK1 unlike SphK2 is critical in human mast cells for antigen-induced degranulation, chemoattractants secretion, and migration, while both isozymes are important for cytokine secretion (Oskeritzian et al., 2008). It should be noted that downregulation of SphK1 also mitigated the rapid and transient increase in intracellular calcium induced by Fc\&RI crosslinking (Melendez and Khaw, 2002). SphKs phosphorylation, probably by Erk, as well as their recruitment to the proximity of cell membrane close to their substrates, are necessary steps for their complete activation (Figure 3). Two Src-family kinases, Lyn and Fyn, play crucial roles in early stages of FceRI activation and are irreplaceable in activations of SphKs. Lyn was found important for the early onset

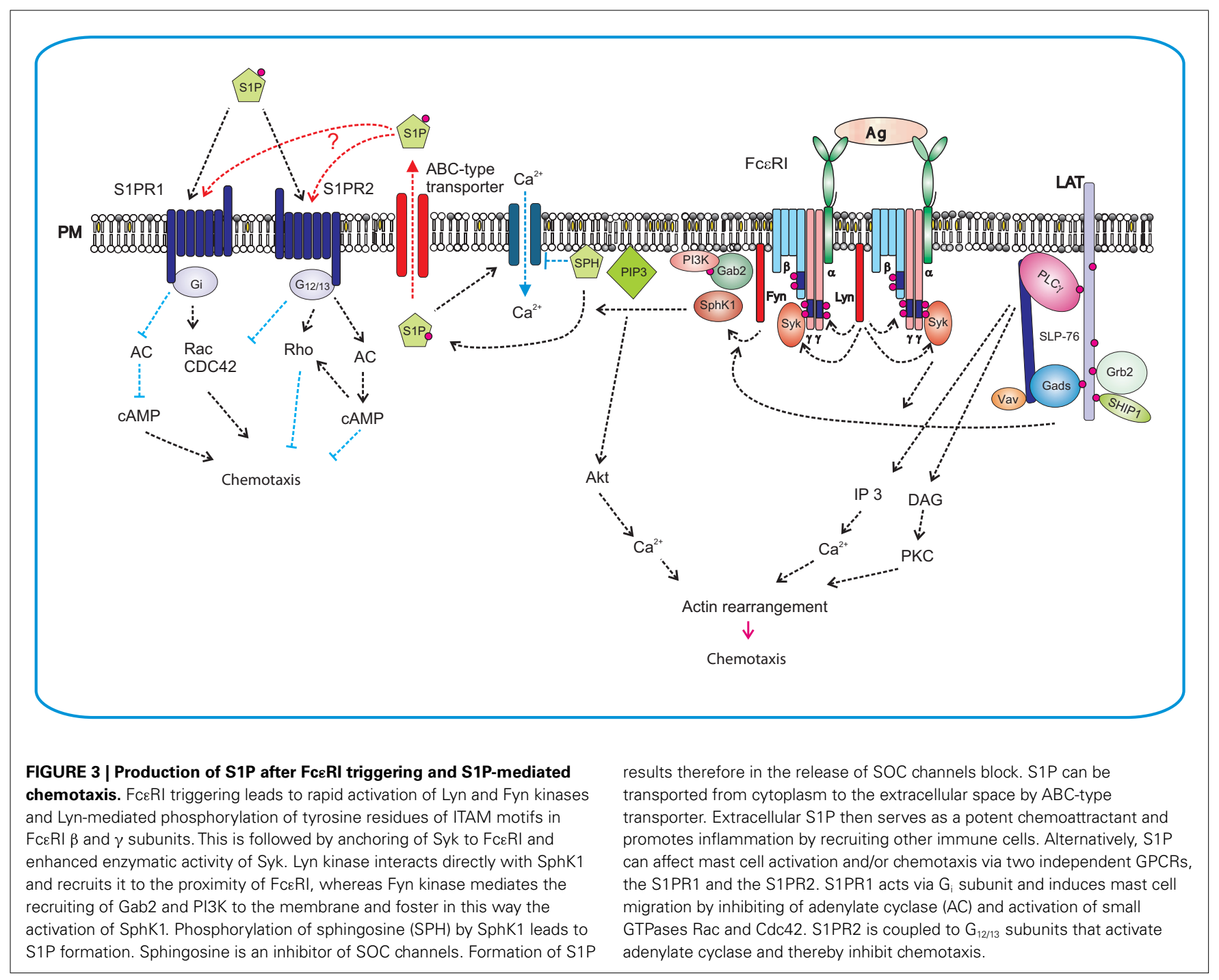


of SphK1 activity by interacting directly with SphK1; this interaction facilitates the recruitment of this lipid kinase to FceRI (Urtz et al., 2004). In contrast, Fyn was found obligatory for activation of both SphKs. Fyn phosphorylates Gab2, which then binds the p85 regulatory subunit of PI3K (Parravicini et al., 2002). Both Gab2 and PI3K activities were essential for SphK1 activation, and were partially responsible for SphK2 activation. This indicates that additional Fyn-dependent, PI3K-independent signals are required for activation of SphK2 (Olivera et al., 2006).

As already mentioned, S1P can mediate mast cell functions through its intracellular and extracellular activities. The intracellular targets of S1P have not yet been fully identified, but a direct correlation was found out between S1P production and uptake of $\mathrm{Ca}^{2+}$. Sphingosine and its structural analogs act as specific inhibitors of SOC influx. Thus, one possible mechanism where by SphK2 might exert its activating effect on calcium influx could be mediated through reduction of the level of sphingosine by its phosphorylation, derepressing in this way the blocking of the SOC channels (Mathes et al., 1998). S1P released from the cells can function as a ligand for a family of five G-protein-coupled S1P receptors (S1PR) 1-5. Evident diversity in the expression pattern of S1PRs can be seen in cells of the immune system. S1PR1 is expressed by most immune cells, whereas other receptors (S1PR2-5) have a more limited distribution. All five receptors were found to be expressed in dendritic cells, whereas mast cells and macrophages express only S1PR1 and S1PR2; eosinophiles express S1PR1-3, T cells S1PR1 and S1PR4, B-cells S1PR1 and S1PR3, and NK cells S1PR5 (Rivera et al., 2008). S1PRs expressed on mast cells can react with S1P by paracrine/autocrine mechanism. S1P levels in tissues increase under inflammatory conditions. Extracellular S1P has chemotactic activity and can attract mast cells to sites of inflammation. Furthermore, S1P produced by mast cells can induce their degranulation and cytokine production. S1PRs, like other GPCRs, transduce signals by associating with G-proteins. S1PR1 interacts with $G_{i}$, which can modulate different pathways leading to cell survival through the PI3K/Akt pathway, cell migration through the PI3K and Rac pathways, and cell proliferation through the Erk pathway. In contrast, S1PR2 is coupled to $G_{i}, G_{q}$, and $\mathrm{G}_{12 / 13}$; the latter two are responsible for degranulation. Experiments with knock-out or knock-down of S1PR1 and/or S1PR2 indicated that these receptors have a non-overlapping function in mast cells. Loss of S1PR1 resulted in decreased chemotactic motility, whereas loss of S1PR2 inhibited mast cell degranulation. Because of the fact that concentrations of S1P required for degranulation were higher than those required for chemotaxis (Jolly et al., 2004) and higher concentrations of S1P also inhibited chemotaxis (Jolly et al., 2005), it has been suggested that mast cells in allergic inflammatory reactions would migrate to target tissues at low S1P concentration gradients. However, after reaching the target, higher S1P concentrations would prevent further migration and the cells could start to degranulate in response to a more extensive ligation of S1PRs (Olivera and Rivera, 2005).

\section{EICOSANOIDS}

Upon activation with specific antigen, complement or other transmembrane stimuli, mast cells produce several eicosanoids through activation of cytoplasmic phospholipase A2 (cPLA2), which releases free arachidonic acid from the plasma membrane (Figure 4). Free arachidonic acid can be metabolized to eicosanoids by three distinct pathways. One depends on the activity of lipoxygenases (LOXs) and leads to production of leukotrienes such as $\mathrm{LTB}_{4}, \mathrm{LTC}_{4}$, and $\mathrm{LTD}_{4}$. The second is dependent on cyclooxygenases (COXs), which are engaged in the mechanisms responsible for production of prostaglandins such as $\mathrm{PGE}_{2}$ and $\mathrm{PGD}_{2}$. The third includes the cytochrome P450 monooxygenase that metabolizes arachidonic acid into epoxyeicosatrienoic acids (EETs), hydroxyeicosatetraenoic acids (HETEs), and hydroperoxyeicosatetraenoic acids (HPETEs; Boyce, 2007; Wang and Dubois, 2010).

As indicated above, the key enzyme in initial stages of these processes is cPLA2. It can be activated by two major routes. One is Erk dependent and results in phosphorylation of the enzyme (Berenbaum et al., 2003), and the other appears to be Erk independent but rides on PI3K/Btk/PLC $\gamma$ pathway enabling $\mathrm{Ca}^{2+}$-dependent translocation of cPLA2 to the membrane (Clark et al., 1991; Kramer and Sharp, 1995, 1997).

Eicosanoids can act as proinflammatory mediators through specific receptors and serve as chemoattractants for various cell types including mast cells and their progenitors. The balance between self-secreted mediators and those produced by other cells is responsible for the paracrine versus autocrine regulation of mast cells (Boyce, 2007). More information on these mediators and their effects on mast cells is given below.

\section{Prostaglandin E2}

Eicosanoid $\mathrm{PGE}_{2}$ is synthesized and secreted in response to inflammatory stimuli by many cell types, including dendritic cells, epithelial cells, fibroblasts, macrophages, and mast cells. Physiological functions of $\mathrm{PGE}_{2}$ are mediated by four types of GPCRs, EP1-4. Each of these receptors is unique in tissue distribution, pharmacology, and action mechanism. The EP1 receptor is coupled to PLC and its stimulation leads to the increase in intracellular $\mathrm{Ca}^{2+}$. Engagement of EP2 and EP4, induces an increase in cAMP level via G-protein $\alpha$-subunit stimulation of adenylate cyclase. EP3 receptor exists in several isoforms generated by alternative splicing; these isoforms are coupled with different $G$-proteins $\left(G_{i}, G_{q}\right.$, and $\left.G_{s}\right)$. The major signaling pathways described for EP3 receptor lead to a decrease in intracellular cAMP levels and increase in intracellular $\mathrm{Ca}^{2+}$ (Ichikawa et al., 1996; Kuehn and Gilfillan, 2007). In FceRItriggered cells, $\mathrm{PGE}_{2}$ regulates activation in positive or negative way, depending on the EP receptors engaged (Figure 5). Enhancement of FceRI-mediated degranulation and cytokine production was described for mouse BMMCs activated by $\mathrm{PGE}_{2}$ bound to EP3 receptor (Gomi et al., 2000; Nataraj et al., 2001; Nguyen et al., 2000) or for human mast cells with $\mathrm{PGE}_{2}$ bound to EP1 or EP3 (Wang and Lau, 2006). Another study reported inhibition of histamine, eicosanoids, and TNF- $\alpha$ production in human mast cells triggered by binding of $\mathrm{PGE}_{2}$ to EP2 receptor, followed by inhibition of elevated cAMP levels (Kay et al., 2006). Recently, $\mathrm{PGE}_{2}$ was described to act as a chemotactic factor for immature as well as mature murine mast cells in vitro (Weller et al., 2007). The same study described accumulation of mast cells in vivo after i.d. injection of $\mathrm{PGE}_{2}$ (Weller et al., 2007). It was also shown that $\mathrm{PGE}_{2}$ mediated chemotactic response in human mast cells (Kuehn 


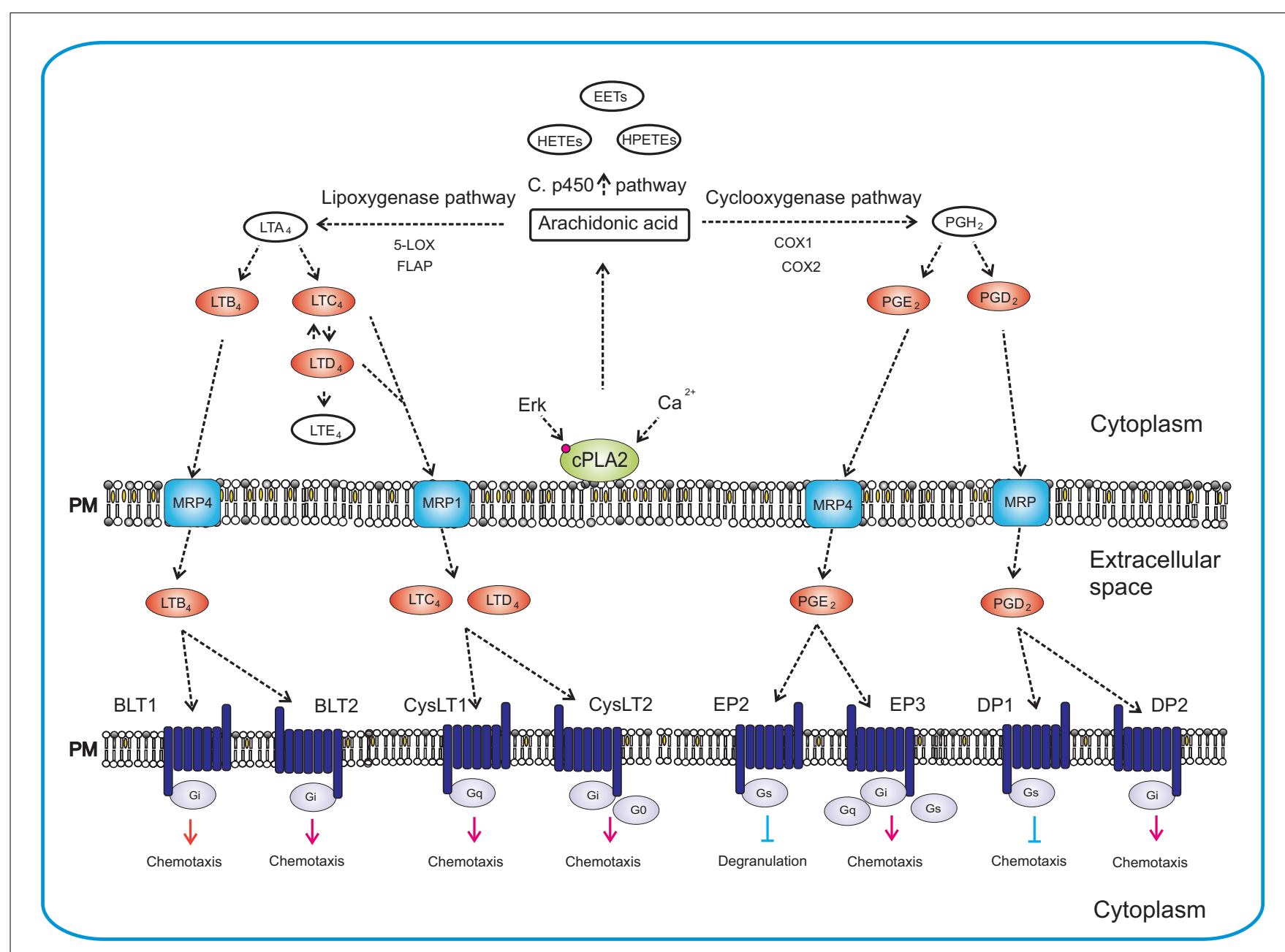

FIGURE 4 | Synthesis of eicosanoids and their actions in mast cells. Synthesis of eicosanoids is initiated by activation of CPLA2 via Erk-dependent pathway, followed by $\mathrm{Ca}^{2+}$-dependent translocation of cPLA2 to the plasma membrane where it liberates the arachidonic acid. Free arachidonic acid can be metabolized by three independent pathways: lipoxygenase pathway, cyclooxygenase pathway and cytochrome P450 monooxygenase pathway. The 5-lipoxygenase in cooperation with FLAP mediates transition of arachidonic acid to unstable $\mathrm{LTA}_{4}$. $\mathrm{LTA}_{4}$ is subsequently converted to $\mathrm{LTB}_{4}$, $\mathrm{LTC}_{4}$, and $\mathrm{LTD}_{4}$. In the cyclooxygenase pathway, arachidonic acid is converted to intermediate $\mathrm{PGH}_{2}$ by peroxidase activity of COX enzymes. $\mathrm{PGH}_{2}$ is then metabolized by specific enzymes to final products that include $\mathrm{PGE}_{2}$ and $\mathrm{PGD}_{2}$. Cytochrome P450 metabolizes arachidonic acid to epoxyeicosatrienoic acids (EETs), hydroperoxyeicosatetraenoic acids (HPETEs), and hydroxyeicosatetraenoic acids (HETEs). The final products are transported outside the cell by specific multidrug resistance protein (MRP) ABC-type transporters and can act there as chemoattractants for mast cells, their progenitors or other cells. Eicosanoids mediate their action via different GPCRs (BLT1, BLT2, CysLT1, CysLT2, EP2, EP3, DP1, and DP2) localized on the plasma membrane of target cells. Eicosanoids in red bodies are those secreted from mast cells and acting as chemoattractants on various targets. et al., 2011a). Biochemical studies showed that $\mathrm{PGE}_{2}$ mediated chemotaxis in mast cells through engagement of GPCRs linked to EP3 receptor. Unlike the FceRI or c-Kit, GPCRs do not require the engagement and activation of tyrosine kinases and protein tyrosine phosphorylation for initial propagation of the signals but reckon instead on coupling to a heterotrimetric complex of $\mathrm{G}_{\alpha}$ and $\mathrm{G}_{\beta \gamma}$ subunits (Dorsam and Gutkind, 2007). PGE 2 activation of the EP3 receptor initiated mobilization of PI3K and Akt, but this pathway in contrast to antigen-mediated triggering, was independent of Btk. Other targets involved in $\mathrm{PGE}_{2}$-induced chemotaxis, downstream of $\mathrm{PI} 3 \mathrm{~K}$, are still vaguely understood. Two forms of mTOR, the mTORC1 and mTORC2, have recently been found to be activated downstream of PI3K in BMMCs and have therefore been suspected to play an important role in
$\mathrm{PGE}_{2}$-mediated chemotaxis. However, pharmacological studies with specific inhibitors of mTORCs as well as siRNA knock-down experiments showed that only mTORC2 cascade was selectively utilized in chemotaxis toward $\mathrm{PGE}_{2}$. EP3-induced chemotaxis thus differs from c-Kit-mediated chemotaxis, which is partly controlled also by mTORC1 (Kim et al., 2008a). Rac-dependent actin reorganization has also been observed in $\mathrm{PGE}_{2}$-mediated chemotaxis but it makes use of a different pathway independent of mTORC2 (Kuehn et al., 2011b).

\section{Prostaglandin D2}

Eicosanoid $\mathrm{PGD}_{2}$ is another arachidonic acid metabolite with important roles in various inflammatory diseases. It is produced by IgE-activated mast cells through the COX pathway (Lewis et al., 


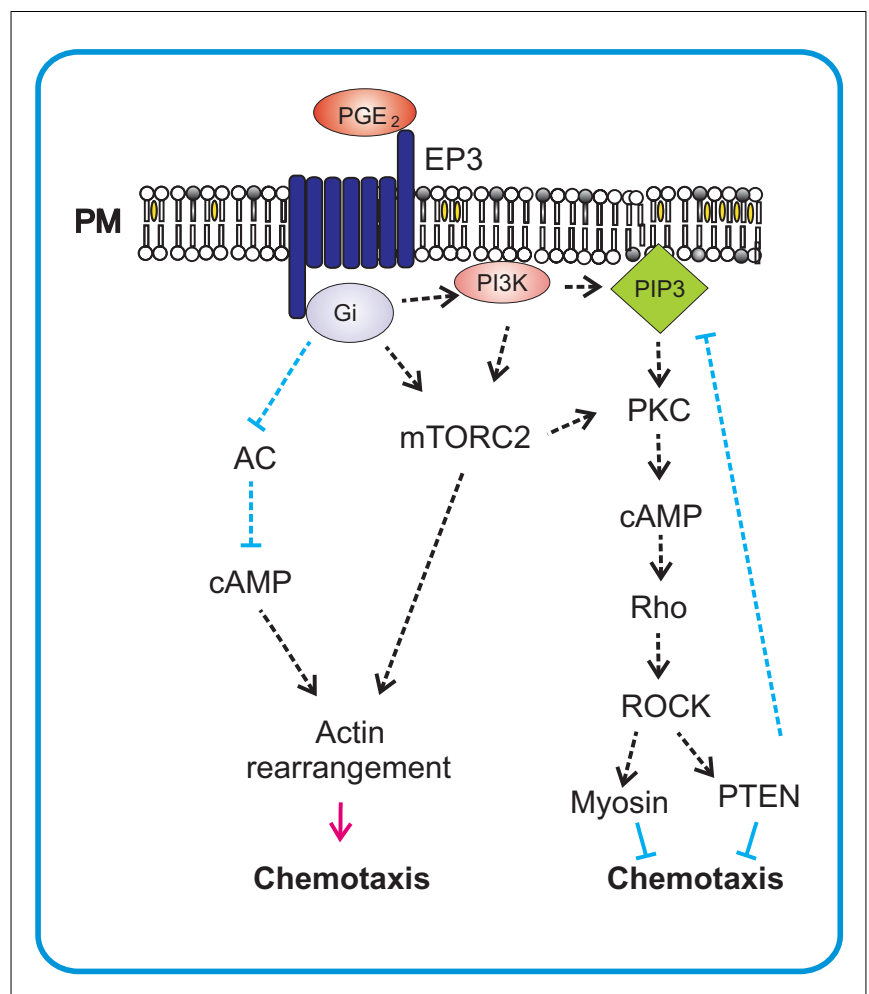

FIGURE 5 | PGE $_{2}$-mediated chemotaxis. PGE $_{2}$ mediates its chemotactic action on mast cells via Gi-coupled EP3 receptor. After activation the $\alpha$-subunit of $\mathrm{G}$-protein inhibits adenylate cyclase (AC) and thereby causes a decrease of CAMP which leads to stimulation of migration. This stimulation also results in activation of mTORC2, an important regulator of actin rearrangements and positive regulator of chemotaxis. mTORC2 can also influence PKC-dependent activation of small GTPase Rho and subsequent activation of PTEN through ROCK. This can act as a negative feedback for production of PIP3 by PI3K that is also activated by $\mathrm{PGE}_{2}$ in mast cells.

1982). $\mathrm{PGD}_{2}$ was found to bind to two different prostaglandin receptors, $\mathrm{G}_{\mathrm{s}}$-coupled DP1 that stimulates adenylate cyclase, and DP2 (also known as chemoattractant receptor-homologous molecule expressed on Th2 cells, CRTH2) that is coupled to $\mathrm{G}_{\mathrm{i}}$. These two membrane-bound receptors show extensively antagonistic effects. $\mathrm{PDG}_{2}$ was found to inhibit migration of several cell types such as dendritic cells and Langerhans cells through the DP1 receptor (Hammad et al., 2003; Angeli et al., 2004; Yamamoto et al., 2011), and to stimulate migration of lymphocytes, eosinophils, and basophils via the DP2 receptor (Hirai et al., 2001; Shiraishi et al., 2005; Yamamoto et al., 2011). The DP2-dependent migration has recently been reported also for mast cells (Boehme et al., 2009).

\section{Leukotriene B4}

Eicosanoid $\mathrm{LTB}_{4}$, as a potent activator and chemoattractant for leukocytes, is implicated in various inflammatory diseases. It is produced from arachidonic acid via the 5-LOX pathway by innate immune cells such as neutrophils, macrophages, and mast cells (Toda et al., 2002; Osher et al., 2006; Ohnishi et al., 2008). The action of $\mathrm{LTB}_{4}$ is mediated by two GPCRs, the BLT1 and BLT2.
BLT1, a high affinity receptor for $\mathrm{LTB}_{4}$, is expressed predominantly in leukocytes including granulocytes, monocytes, macrophages, dendritic cells, effector T cells, and mast cells (Yokomizo et al., 1997; Yokomizo et al., 2000), whereas BLT2, a low affinity receptor which can also bind to some other eicosanoids is expressed ubiquitously (Yokomizo et al., 2000). Both BLT1 and BLT2 couple to the inhibitory $G_{i}$ protein, inhibit adenylate cyclase, activate PLC $\gamma$ to increase intracellular $\mathrm{Ca}^{2+}$, and induce robust chemotaxis (Yokomizo, 2011). Mouse BLT2 is highly expressed in small intestine and skin, and BLT2-selective agonist induces chemotaxis in primary mouse keratinocytes and BMMCs. Triggering of BMMCs by $\mathrm{LTB}_{4}$ induces transient Erk and Akt phosphorylation without any changes of p38 phosphorylation (Lundeen et al., 2006).

$\mathrm{LTB}_{4}$ serves as a potent chemoattractant for mast cell progenitors, but not mature mast cells (Weller et al., 2005). It was also shown that BLT2 is upregulated in cells activated via FceRI. Knock-down of BLT2 resulted in reduced NOX1-Ros-mediated production of Th2 cytokines such as IL-4 and IL-13 (Cho et al., 2010). On the other hand, exposure of BMMCs to SCF, another chemoattractant and activator, resulted in downregulation of BLT1 and BLT2 expression and inhibition of migration toward $\mathrm{LTB}_{4}$ (Lundeen et al., 2006).

\section{Leukotriene D4 and Leukotriene C4}

Similarly to $\mathrm{LTB}_{4}$, the $\mathrm{LTD}_{4}$, and $\mathrm{LTC}_{4}$ are produced in activated mast cells via the LOX pathway (Razin et al., 1983). These two leukotrienes act through two specific receptors CysLT1 and CysLT2 that have non-redundant functions in mast cells and are coupled to distinct intracellular signaling pathways. CysLT1 receptor is bound to $G_{q}$ proteins, whereas CysLT2 receptor uses $G_{i} / G_{o}$ proteins for calcium-independent signaling (Bautz et al., 2001; Möhle et al., 2001; Mellor et al., 2003). Both $\mathrm{LTD}_{4}$ and $\mathrm{LTC}_{4}$ were found to function as co-mitogens for low concentrations of SCF (Jiang et al., 2006, 2007). LTD4 induces migration and transendothelial migration of $\mathrm{CD} 34^{+}$mast cell progenitors (Bautz et al., 2001).

\section{CHEMOKINES}

Chemokines are members of a superfamily of $8-15 \mathrm{kDa}$ heparinbinding chemotactic cytokines that function as potent chemoattractants for different cell types in the immune system. Although they are not homologous sequentially, they share a similar three-dimensional structure. There are four subclasses of chemokines classified according to the location of the first two cysteines in their sequence: CC, CXC, C, and CX3C (where X stands for any amino acid). Major families, the $\mathrm{CC}$ and $\mathrm{CXC}$, have more than 50 members, whereas $\mathrm{C}$ and $\mathrm{CX} 3 \mathrm{C}$ families are much smaller with only one or a few members per family. Some chemokines are expressed constitutively by many cell types in tissue-specific manner. Expression of other chemokinesis induced only under specific conditions, typically in response to inflammatory signals (Kaplan, 2001; Sabroe et al., 2002; Juremalm and Nilsson, 2005; Scott and Bradding, 2005; Lloyd and Brown, 2006; Hallgren and Gurish, 2011). Chemokine receptors belong to GPCRs, and are mostly capable of binding more than one chemokine. Considerable differences in the expression of chemokine receptors exist between mature and immature mast cells and among individual mast cell 
subtypes. For example, mast cells derived from progenitors present in human cord blood express several chemokine receptors including CCR3 (eotaxin receptor), CCR5 [receptor for the Th1-active chemokine macrophage inflammatory protein (MIP)-1 $\alpha$ ], CXCR2 (IL-8 receptor), and CXCR4 [receptor for the constitutively produced lymphocyte chemoattractant stromal cell-derived factor (SDF) $-1 \alpha]$. Only the CCR3 was retained on mature human mast cells (Ochi et al., 1999; Bautz et al., 2001).

Chemokines exhibit a different pattern of expression depending on mast cell type. For example, CCR3, CXCR1, CXCR3, and CXCR4 were found to be highly expressed by human LMCs, and their respective ligands, i.e., CCL11 (eotaxin), CXCL8 (IL8), CXCL10, interferon $\gamma$-induced protein (IP)-10, and CXCL12 (SDF-1 $\alpha$ ), mediated LMC chemotaxis (Brightling et al., 2005a,b). Interestingly, the CXCR3 was missing among those reported to be expressed on human BMMCs. Cord blood-derived mast cells and LMCs from patients with allergic asthma expressed CCR1 and CCR4 (Juremalm et al., 2000, 2002; Amin et al., 2005) and CCR3 was expressed in human skin and intestinal mast cells (Romagnani et al., 1999). Recent work testing the expression of chemokines and chemokine receptors showed that human intestinal mast cells expressed nine chemokine receptors (CCR6-8, CXCR1-4, XCR1, and CX3CR1) and 27 chemokines. Whereas expression of chemokine receptors was independent of antigen stimulation, the expression of 12 chemokines (CCL1-CCL5, CCL7, CCL18, CCL20, CXCL2, CXCL3, CXCL8, and XCL1) was more than fourfold upregulated upon antigen triggering (Feuser et al., 2012).

Mouse mast cells also express several chemokine receptors. Studies with mouse BMMCs showed expression of mRNA for CCR1-5 and its upregulation after activation through c-kit or FceRI (Oliveira and Lukacs, 2001). Chemotaxis assays showed that mast cells migrated toward CCL2 and CCL5. If IgE-sensitized cells were exposed to antigen, enhanced migration was also observed toward CXCL4 and CCL3 (Taub et al., 1995). In another study mouse BMMCs expressed CCR3 mRNA, but the corresponding protein was not detected and migration toward CCR3 ligands (CCL11 and CCL24) was noticed neither in mature nor immature cells. In addition, no phenotypic differences between WT and $\mathrm{CCR}^{-1-}$ mice were found (Collington et al., 2010b, 2011). The observed differences could be attributed to different mouse strains chosen or different methods used for growth of the cells. The first group (Oliveira and Lukacs, 2001) cultured BMMCs in the presence of IL-3 and SCF (both at a concentration of $15 \mathrm{ng} / \mathrm{ml}$ ), whereas in the second study only IL-3 at $5 \mathrm{ng} / \mathrm{ml}$ was used. The data also suggest that the role of CCR3 in chemotaxis depends not only on cell origin (mouse versus human) but also on physiological settings. Expression of different chemokines could be responsible for mast cell homing into different tissue. Impaired homing was found in mouse mast cell progenitors lacking genes for selected chemokine receptors. When CXCR2 ${ }^{-1-}$ cells were used, mast cells were absent in intestine but still present in lung, spleen, or bone marrow (Abonia et al., 2005). Homing to intestines was unaltered in mice lacking CCR2, CCR3, and CCR5. On the other hand, knock-out of CCR3 led to an increased number of intratracheal mast cells (Humbles et al., 2002; Hallgren and Gurish, 2007; Hallgren et al., 2007). Immature BMMCs, when cultured in the presence of IL-3 and SCF but not IL-3 alone, migrated in response to CCL2. Recruitment of mast cell progenitors to the allergensensitized lungs was significantly reduced in both CCR $2^{-/-}$and CCL2 ${ }^{-1-}$ mice. However, repopulation studies using sublethally irradiated and bone marrow reconstituted mice indicated that receptor and ligand expression was more important on stromal cells than mast cells (Collington et al., 2010a). Dermal mast cells were found to play a critical role in the induction of immune suppression. UV exposure caused increased migration of mast cells from skin to the draining lymph nodes. This was mediated by interaction of CXCR4 expressed on mast cells with CXCL12 that is up regulated in lymph node B-cells (Byrne et al., 2008).

Murine BMMCs of both connective tissue and mucosal phenotype were also found to express CX3CR1 and were attracted by its chemoattractant CX3CL1 (fractalkine), which is a membranebound peptide. Fractalkine was unable to induce degranulation quantified by the release of granule-associated $\beta$-hexosaminidase (Papadopoulos et al., 2000).

\section{TRANSFORMING GROWTH FACTOR $\beta$}

Multifunctional transforming growth factor (TGF)- $\beta$ is a peptide that plays a key role in tissue cell growth, differentiation, morphogenesis, and formation of extracellular matrix, as well as in coordination of the complex events leading to tissue repair after injury. Its pivotal function within the immune system is to maintain tolerance by regulating the lymphocyte proliferation, differentiation, and survival. Furthermore, TGF- $\beta$ controls the initiation and resolution of inflammatory responses through the regulation of chemotaxis and activation of lymphocytes, dendritic cells, natural killer cells, granulocytes, and mast cells. Through its pleiotropic effect on various immune cells, TGF- $\beta$ prevents the development of autoimmune diseases without compromising the efficiency of immune responses toward pathogens (Wrzesinski et al., 2007). Initial studies on chemotaxis showed that TGF- $\beta$ at femtomolar concentrations caused directed migration of cultured mouse cells, with maximal chemotactic response observed at $25 \mathrm{fM}$. In its ability to induce directed migration, TGF- $\beta$ was substantially more efficient on the molar basis than other mast cell chemoattractants, including SCF (Gruber et al., 1994). Detailed studies showed that TGF- $\beta 3$, one of the three isoforms of TGF$\beta$, was more effective than TGF- $\beta 1$ and TGF- $\beta 2$ when tested at a constant concentration of $40 \mathrm{fM}$. The effect was observed in both human mast cell line HMC-1 and cultured primary mast cells. Furthermore, TGF- $\beta 1$, TGF- $\beta 2$, and less efficiently TGF- $\beta 3$ inhibited the proliferation of HMC-1 cells. The migratory responses were probably mediated through interaction of all TGF- $\beta$ isoforms with TGF- $\beta$ serine/threonine type I and II receptors that were found expressed in HMC-1 cells (Olsson et al., 2000). Application of peptidoglycan from Staphylococcus aureus to barrier-disrupted abdominal skin lead to accumulation of mast cells at the site of application. This accumulation was abrogated by administration of TGF- $\beta 1 \mathrm{Ab}$. These results suggest that peptidoglycan have ability to induce mast cell accumulation through TGF- $\beta 1$ production by epidermal keratinocytes (Matsui and Nishikawa, 2005). All combined, the data indicate that TGF- $\beta$ isoforms are highly potent chemoattractants for mast cells and could possibly play an important role in the recruitment of mast cells to the sites of inflammatory reactions. 


\section{ADENOSINE}

The purine nucleoside adenosine is produced by numerous cell types in response to cell stress and hypoxia. It binds to four types of adenosine receptors, $A_{1}, A_{2 A}, A_{2 B}$, and $A_{3}$. The latter three were found expressed on mast cells (Ramkumar et al., 1993; Ralevic and Burnstock, 1998). These receptors are GPCRs and are coupled to different G-proteins: $A_{2 A}$ receptor to $G_{s}, A_{2 B}$ to $G_{s}$ or $G_{q}$ and $A_{3}$ to $G_{i}$ or $G_{q}$ (Kuehn and Gilfillan, 2007). Adenosine regulates mast cell activities positively or negatively, depending on the plasma membrane receptor involved and mast cell type (Kuehn and Gilfillan, 2007; Brown et al., 2008). It has been reported that adenosine regulates FceRI-mediated mast cell degranulation, cytokine production, and chemotaxis. Binding of adenosine to $\mathrm{A}_{2 \mathrm{~A}}$ receptor also blocked the potassium channel, KCa3.1, and inhibited migration of human LMCs in response to asthmatic airway smooth muscle conditioned medium (Duffy et al., 2007). Adenosine alone was unable to cause migration of BMMCs but it potentiated the migration toward antigen in a pertussis-toxin dependent manner. This points to $A_{3}$ receptor coupled to $G_{i}$ (Kuehn et al., 2010). It may possible be relevant that purine and pyrimidine nucleotides ADP, ATP, and UTP, acting at low micromolar concentrations, also caused directed migration of rat BMMCs (McCloskey et al., 1999).

\section{Other chemoattractants}

There are several other molecules that are recognized by mast cells as chemoattractants. Human $\mathrm{Clq}$ is a collagen-like glycoprotein that associates with the $\mathrm{Ca}^{2+}$-dependent $\mathrm{Clr}_{2} \mathrm{Cls}_{2}$ tetramer, forming the first component of complement, $\mathrm{C} 1$. C1q induces mast cell migration in a specific and dose-dependent manner. Two specific receptors were found on murine and human mast cells, the cC1q$\mathrm{R}$ that binds to the collagen-like stalk of Clq, and the gC1q-R that binds to the globular "heads" of C1q (Ghebrehiwet et al., 1995).

C3a and C5a are other complement components which are potent chemoattractants for eosinophils and neutrophils but in addition can attract mast cells and basophils. The chemotactic response is blocked by pertussis-toxin, suggesting that $\mathrm{G}_{\mathrm{i}}$-coupled receptors are involved in signal transduction (Nilsson et al., 1996; Hartmann et al., 1997).

Platelet-activating factor (PAF) is a potent phospholipid inflammatory mediator that is released from a variety of cells, including endothelial cells, neutrophils, and macrophages. PAF acts via binding to a specific GPCR. PAF was also found to induce mast cell migration in pertussis-toxin dependent manner this indicates that $\mathrm{G}_{\mathrm{i}}$-coupled receptor is involved in this process (Nilsson et al., 2000).

Another chemoattractant, the 5-hydroxytryptamine (5-HT), is implicated in enhancing inflammatory reactions of skin, lung, and gastrointestinal tract. It was reported that both human and mouse mast cells expressed a variety of 5-HT GPCRs, but the predominant receptor mediating the effects like adhesion and migration on these cells was the 5-HT1A G $\mathrm{G}_{\mathrm{i}}$-coupled receptor. Mast cells also synthesize 5-HT, which can function in both paracrine and autocrine manner (Kushnir-Sukhov et al., 2006).

Recently published studies also showed that the neuroendocrine peptide catestatin, as well as its naturally occurring variants were capable of inducing migration, degranulation, and production of cytokines, eicosanoids, and chemokines, in both human mast cell line LAD-2 and peripheral blood-derived mast cells (Aung et al., 2011).

Furthermore, proinflammatory cytokines were capable of inducing chemotaxis. Mast cells were shown to migrate in response to IL-6 or TNF- $\alpha$ stimulation. IL-6-stimulated mast cell migration was the result of chemokinesis, whereas TNF- $\alpha$-induced migration was based on chemotaxis (Brzezińska-Błaszczyk et al., 2007; Misiak-Tloczek and Brzezińska-Blaszczyk, 2009). In contrast, IL10 inhibited mast cell migration toward RANTES, TNF- $\alpha$, and nerve growth factor (Pietrzak et al., 2011).

Mast cells were also found to accumulate in proximity of various malignant tumors. It has been shown that tumor-derived tripeptides glycylhistidyllysine and $\mathrm{N}$-formyl-methionyl-leucylphenylalanine are potent chemoattractants for rat peritoneal mast cells, suggesting that they could be important in early events of tumor neovascularization (Poole and Zetter, 1983). Adrenomedullin is another peptide amid produced by human cancer cells that was found to be chemotactic for HMC-1 (Zudaire et al., 2006).

\section{LESSONS FROM OTHER CELLS}

There exist two important cellular models for studying chemotaxis of eukaryotic cells, neutrophils, and Dictyostelium. Both can detect very shallow differences in the surrounding gradients of chemoattractants and are thereby capable of quickly changing directions of their movement. Because GPCRs that have often been the subjects of studied on chemotaxis of the two cell types are also involved in migration of mast cells, the knowledge obtained in studies on neutrophils and Dictyostelium can be helpful for better understanding of chemotaxis in mast cells. In migrating cells, two sides can be distinguished, the front side (also called leading edge) and the rear side. Concentration of chemoattractants reaching the cell surface is, consequently highest in the front and lowest in the rear. In both, neutrophils and Dictyostelium, one of the first processes occurring in the leading edge after sensing chemoattractant is activation of PI3K resulting in accumulation of PIP3 in the leading edge membrane (Nilsson et al., 1996; Hartmann et al., 1997; Funamoto et al., 2001, 2002; Huang et al., 2003). PIP3 than serves as a binding site for a diversity of pleckstrin homology $(\mathrm{PH})$-domain containing proteins. The most important proteins recruited appear to be guanine nucleotide exchange factors (GEFs) for Rac GTPases, such as dedicators of cytokinesis (DOCKs). Their recruitment leads to activation of small GTPase Rac and subsequently localized polymerization of F-actin. The rear side of neutrophils is engaged in activation of another small GTPase RhoA that activates ROCK and makes thus possible the phosphorylation of myosin light chain. These signals are mediated by different G-proteins. At the leading edge, it is mediated by a $\mathrm{G}_{\mathrm{i}}$-coupled protein which inhibits adenylate cyclase, whereas $G_{12 / 13}$ promote back signal by myosin II. Despite the fact that generating PIP3 is crucial for cell migration, inhibition of PIP3 formation in neutrophils (Ferguson et al., 2007; Heit et al., 2008), or in Dictyostelium (Loovers et al., 2006; Andrew and Insall, 2007) did not, at least under certain circumstances, fully inhibited cell migration, but only slowed it down. The data suggest that PIP3 accumulation is not essential for direction of chemotaxis but controls the extent of random generation of pseudopodia. The steep PIP3 gradient is also controlled by 
degradation of PIP3 by phosphatases, mainly at the rear side of the migrating cell. PTEN was found to be a dominant phosphatase for PIP3 degradation in Dictyostelium (Funamoto et al., 2002; Iijima et al., 2002, 2004). In contrast, PTEN played only a minor role in chemotaxis of neutrophils (Subramanian et al., 2007) where SHIP1 was the major regulator (Nishio et al., 2007). This finding was supported by experiments indicating that neutrophils lacking SHIP1 exhibited severe defects in neutrophil polarization and motility. In macrophages, PTEN was found to control PI3K activity via negative feedback including the PI3K/Rho/ROCK pathway (Papakonstanti et al., 2007). These results show that several alternative pathways are involved in chemotaxis. One of them could involve another lipid signaling pathway parallel to PI3K and mediated through phospholipase A2 (PLA2; Chen et al., 2007). Each of these pathways can inhibit chemotaxis in shallow gradients, whereas inhibition of chemotaxis in steep gradients requires both pathways to be disrupted (Kolsch et al., 2008; Wang et al., 2011).

The behavior of cells in different concentration gradients is diverse. In steep gradients, neutrophils and Dictyostelium can project pseudopodia directly up the gradient and move toward the chemoattractant source with only little deviation. In shallower gradients, cells produce daughter pseudopods and then choose the one that leads up to the highest concentration of chemoattractant. However, in the weakest gradients the movement of neutrophils and Dictyostelium looks like a biased random walk (Kay et al., 2008; Insall, 2010). Key regulators of cellular polarity in migrating neutrophils and Dictyostelium are mTORC2 (Liu et al., 2010) and TORC2 (Lee et al., 2005). Neutrophils lacking mTORC2 activity had strongly reduced chemotactic ability, and were unable to polarize. Actin polymerization and myosin II regulation were impaired independently. Also production of cAMP was affected. The effect of mTORC2 on myosin II filament assembly was mediated via cAMP, RhoA, and ROCK-dependent way (Charest and Firtel, 2010; Charest et al., 2010; Liu et al., 2010). Myosin phosphorylation stimulates its activity but the stability of myosin filaments is regulated by its dephosphorylation. Based on these and other studies it was concluded that activation of the receptors triggers both promoting and inhibiting signals for myosin phosphorylation and dephosphorylation, and this cycling is important for optimal migration (Liu et al., 2010). A recent study with Dictyostelium mutants focused on better understanding of the roles of PI3K, TORC2, PLA2, and soluble guanylate cyclase in chemotaxis in gradients of different strength. The study showed that Ras activation at the leading edge was a basal signaling module sufficient for chemotaxis in this system. The enzymes under study were not required for Ras activation in steep gradients of cAMP

\section{REFERENCES}

Abonia, J. P., Austen, K. F., Rollins, B. J., Joshi, S. K., Flavell, R. A., Kuziel, W. A., Koni, P. A., and Gurish, M. F. (2005). Constitutive homing of mast cell progenitors to the intestine depends on autologous expression of the chemokine receptor CXCR2. Blood 105, 4308-4313.

Amin, K., Janson, C., Harvima, I., Venge, P., and Nilsson, G. (2005).

but were important for the direction and improved orientation in shallow cAMP gradients (Kortholt et al., 2011).

\section{CONCLUDING REMARKS}

Mast cells are known for their role in allergy and as effector cells of innate immunity. They are distributed everywhere in the body and are enriched at boundaries of the body, such as respiratory and gastrointestinal mucosa and skin. They are also found near blood vessels and nerve endings where they contribute to protection against various pathogens. They must be recruitable to all these sites by precise cumulation mechanisms to warrant equal distribution without any crowding or insufficient representation in some places. This would explain why mast cells have so many surface receptors involved in chemotaxis. On the other hand, an important homeostatic role of a crosstalk between mast cells and other immune and non-immune cells and its enhancement after mast cell triggering could explain why mast cells produce so many chemoattractants and why this production is enhanced after mast cell activation. Furthermore, mast cells of human and mouse origin also differ in the expression of chemoattractant receptors and chemoattractants produced (Table $\mathbf{1}$ ).

Although numerous molecules have been identified as significant players in chemotaxis, it is very likely that other molecules involved in chemotaxis will be discovered. Some controversial results mentioned in this review are attributable to different mast cell types used, various methods used for detection of chemotaxis or some additional factors like culture conditions, number of passages of in vitro cultured cells before the cells are used, origin of mast cells, age and genotype of donors and others. The crosstalk between different receptors and signaling molecules is still an open question, which remains also to be solved. Important data reflecting cellular potential and commitment can be expected from analysis of whole genome transcriptome of the cells under study and from application of methods of systems biology in studies of mast cell chemotaxis under in vitro and in vivo conditions.

\section{ACKNOWLEDGMENTS}

Work on mast cell signaling and chemotaxis in the laboratory of the authors has been funded, over the years, by several projects, including LD12073 COST-CZ-MAST from Ministry of Education, Youth and Sports of the Czech Republic; 301/09/1826, P302/10/1759, and P302/12/G101 from the Grant Agency of the Czech Republic; M200520901 and Institutional project RVO 68378050 from Academy of Sciences of the Czech Republic; and Action BM1007 from European Cooperation in Science and Technology.

the induction of angiogenic vascular maturation. J. Biol. Chem. 277, 6667-6675.

Andrew, N., and Insall, R. H. (2007). Chemotaxis in shallow gradients is mediated independently of PtdIns 3-kinase by biased choices between random protrusions. Nat. Cell Biol. 9, 193-200.

Angeli, V., Staumont, D., Charbonnier, A. S., Hammad, H., Gosset,
P., Pichavant, M., Lambrecht, B. N., Capron, M., Dombrowicz, D., and Trottein, F. (2004). Activation of the $\mathrm{D}$ prostanoid receptor 1 regulates immune and skin allergic responses. J. Immunol. 172, 3822-3829.

Aung, G., Niyonsaba, F., Ushio, H., Kajiwara, N., Saito, H., Ikeda, S., Ogawa, H., and Okumura, K. (2011). Catestatin, a neuroendocrine antimicrobial peptide, induces human 
mast cell migration, degranulation and production of cytokines and chemokines. Immunology 132, 527-539.

Bautz, F., Denzlinger, C., Kanz, L., and Mohle, R. (2001). Chemotaxis and transendothelial migration of $\mathrm{CD}_{3} 4^{+}$hematopoietic progenitor cells induced by the inflammatory mediator leukotriene D4 are mediated by the 7-transmembrane receptor CysLT1. Blood 97, 3433-3440.

Berenbaum, F., Humbert, L., Bereziat, G., and Thirion, S. (2003). Concomitant recruitment of ERK1/2 and p38 MAPK signalling pathway is required for activation of cytoplasmic phospholipase A2 via ATP in articular chondrocytes. J. Biol. Chem. 278, 13680-13687.

Boehme, S. A., Franz-Bacon, K., Chen, E. P., Ly, T. W., Kawakami, Y., and Bacon, K. B. (2009). Murine bone marrow-derived mast cells express chemoattractant receptor-homologous molecule expressed on T-helper class 2 cells (CRTh2). Int. Immunol. 21, 621-632.

Boyce, J. A. (2007). Mast cells and eicosanoid mediators: a system of reciprocal paracrine and autocrine regulation. Immunol. Rev. 217, 168-185.

Brdička, T., Imrich, M., Angelisová, P., Brdičková, N., Horváth, O., Špička, J., Hilgert, I., Lusková, P., Dráber, P., Novák, P., Engels, N., Wienands, J., Simeoni, L., Osterreicher, J., Aguado, E., Malissen, M., Schraven, B., and Hořejší, V. (2002). Non-T cell activation linker (NTAL): a transmembrane adaptor protein involved in immunoreceptor signaling. J. Exp. Med. 196, 1617-1626.

Brightling, C. E., Ammit, A. J., Kaur, D., Black, J. L., Wardlaw, A. J., Hughes, J. M., and Bradding, P. (2005a). The CXCL10/CXCR3 axis mediates human lung mast cell migration to asthmatic airway smooth muscle. Am. J. Respir. Crit. Care Med. 171, 1103-1108.

Brightling, C. E., Kaur, D., Berger, P., Morgan, A. J., Wardlaw, A. J., and Bradding, P. (2005b). Differential expression of CCR3 and CXCR3 by human lung and bone marrowderived mast cells: implications for tissue mast cell migration. J. Leukoc. Biol. 77, 759-766.

Brown, R. A., Spina, D., and Page, C. P. (2008). Adenosine receptors and asthma. Br. J. Pharmacol. 153, S446S456.

Brzezińska-Blaszczyk, E., Pietrzak, A., and Misiak-Tloczek, A. H. (2007). Tumor necrosis factor (TNF) is a potent rat mast cell chemoattractant. J. Interferon Cytokine Res. 27, 911-920.

Buday, L., Egan, S. E., Rodriguez, V. P., Cantrell, D. A., and Downward, J. (1994). A complex of Grb2 adaptor protein, Sos exchange factor, and a $36-\mathrm{kDa}$ membrane-bound tyrosine phosphoprotein is implicated in Ras activation in T cells. J. Biol. Chem. 269, 9019-9023.

Byrne, S. N, Limón-Flores, A. Y., and Ullrich, S. E. (2008). Mast cell migration from the skin to the draining lymph nodes upon ultraviolet irradiation represents a key step in the induction of immune suppression. J. Immunol. 180, 4648-4655.

Chabot, B., Stephenson, D. A., Chapman, V. M., Besmer, P., and Bernstein,A. (1988). The proto-oncogene c-kit encoding a transmembrane tyrosine kinase receptor maps to the mouse W locus. Nature 335, 88-89.

Charest, P. G., and Firtel, R. A. (2010). “TORCing” neutrophil chemotaxis. Dev. Cell 19, 795-796.

Charest, P. G., Shen, Z., Lakoduk, A., Sasaki, A. T., Briggs, S. P., and Firtel, R. A. (2010). A Ras signaling complex controls the RasC-TORC2 pathway and directed cell migration. Dev. Cell 18, 737-749.

Chen, L., Iijima, M., Tang, M., Landree, M. A., Huang, Y. E., Xiong, Y., Iglesias, P. A., and Devreotes, P. N. (2007). PLA2 and PI3K/PTEN pathways act in parallel to mediate chemotaxis. Dev. Cell 12, 603-614.

Cho, K. J., Seo, J. M., Lee, M. G., and Kim, J. H. (2010). BLT2 Is upregulated in allergen-stimulated mast cells and mediates the synthesis of Th2 cytokines. J. Immunol. 185, 6329-6337.

Clark, J. D., Lin, L. L., Kriz, R. W., Ramesha, C. S., Sultzman, L. A., Lin, A. Y., Milona, N., and Knopf, J. L. (1991). A novel arachidonic acid-selective cytosolic PLA2 contains a $\mathrm{Ca}^{2+}$-dependent translocation domain with homology to PKC and GAP. Cell 65, 1043-1051.

Collington, S. J., Hallgren, J., Pease, J. E., Jones, T. G., Rollins, B. J., Westwick, J., Austen, K. F., Williams, T. J., Gurish, M. F., and Weller, C. L. (2010a). The role of the CCL2/CCR2 axis in mouse mast cell migration in vitro and in vivo. J. Immunol. 184, 6114-6123.

Collington, S. J., Westwick, J., Williams, T. J., and Weller, C. L. (2010b). The function of CCR3 on mouse bone marrow-derived mast cells in vitro. Immunology 129, 115-124.

Collington, S. J., Williams, T. J., and Weller, C. L. (2011). Mechanisms underlying the localisation of mast cells in tissues. Trends Immunol. 32, 478-485.

Cooper, P. H., and Stanworth, D. R. (1976). Isolation of rat peritoneal mast cells in high yield and purity. Methods Cell. Biol. 14, 365-378.

de Paulis, A., Annunziato, F., Di Gioia, L., Romagnani, S., Carfora M., Beltrame, C., Marone, G., and Romagnani, P. (2001) Expression of the chemokine receptor CCR3 on human mast cells. Int. Arch. Allergy Immunol. 124, 146-150.

Dorsam, R. T., and Gutkind, J. S. (2007). G-protein-coupled receptors and cancer. Nat. Rev. Cancer 7 , 79-94.

Dráber, P., and Dráberová, L. (2005). Lifting the fog in store-operated $\mathrm{Ca}^{2+}$ entry. Trends Immunol. 26, 621-624.

Draber, P., Halova, I., Levi-Schaffer, F., and Draberova, L. (2012). Transmembrane adaptor proteins in the high-affinity IgE receptor signaling. Front. Immun. 2:95. doi:10.3389/fimmu.2011.00095

Duffy, S. M., Cruse, G., Brightling, C. E., and Bradding, P. (2007). Adenosine closes the $\mathrm{K}^{+}$channel KCa3.1 in human lung mast cells and inhibits their migration via the adenosine A2A receptor. Eur. J. Immunol. 37, 1653-1662.

Eiseman, E., and Bolen, J. B. (1992). Engagement of the high-affinity IgE receptor activates src proteinrelated tyrosine kinases. Nature 355 , 78-80.

Ferguson, G. J., Milne, L., Kulkarni, S., Sasaki, T., Walker, S., Andrews, S., Crabbe, T., Finan, P., Jones, G., Jackson, S., Camps, M., Rommel, C., Wymann, M., Hirsch, E., Hawkins, P., and Stephens, L. (2007). PI(3)K $\gamma$ has an important context-dependent role in neutrophil chemokinesis. Nat. Cell Biol. 9, 86-91.

Feuser, K., Thon, K.-P., Bischoff, S. C., and Lorentz, A. (2012). Human intestinal mast cells are a potent source of multiple chemokines. Cytokine 58, 178-185.

Finco, T. S., Kadlecek, T., Zhang, W., Samelson, L. E., and Weiss, A. (1998). LAT is required for TCR-mediated activation of PLC $\gamma 1$ and the Ras pathway. Immunity 9, 617-626.

Fox, C. C., Dvorak, A. M., Peters, S. P., Kagey-Sobotka, A., and Lichtenstein, L. M. (1985). Isolation and characterization of human intestinal mucosal mast cells. J. Immunol. 135, 483-491.

Funamoto, S., Meili, R., Lee, S., Parry, L., and Firtel, R. A. (2002). Spatial and temporal regulation of 3 phosphoinositides by PI 3-kinase and PTEN mediates chemotaxis. Cell 109, 611-623.

Funamoto, S., Milan, K., Meili, R., and Firtel, R. A. (2001). Role of phosphatidylinositol 3' kinase and a downstream pleckstrin homology domain-containing protein in controlling chemotaxis in Dictyostelium. J. Cell Biol. 153, 795-810.

Furumoto, Y., Brooks, S., Olivera, A., Takagi, Y., Miyagishi, M., Taira, K., Casellas, R., Beaven, M. A., Gilfillan, A. M., and Rivera, J. (2006). Cutting edge: lentiviral short hairpin RNA silencing of PTEN in human mast cells reveals constitutive signals that promote cytokine secretion and cell survival. J. Immunol. 176, 5167-5171.

Ghebrehiwet, B., Kew, R. R., Gruber, B. L., Marchese, M. J., Peerschke, E. I., and Reid, K. B. (1995). Murine mast cells express two types of $\mathrm{Clq}$ receptors that are involved in the induction of chemotaxis and chemokinesis. J. Immunol. 155, 2614-2619.

Gilliland, L. K., Schieven, G. L., Norris, N. A., Kanner, S. B., Aruffo, A., and Ledbetter, J. A. (1992). Lymphocyte lineage-restricted tyrosinephosphorylated proteins that bind PLC $\gamma 1$ SH2 domains. J. Biol. Chem. 267, 13610-13616.

Gomi, K., Zhu, F. G., and Marshall, J. S. (2000). Prostaglandin E2 selectively enhances the IgE-mediated production of IL- 6 and granulocytemacrophage colony-stimulating factor by mast cells through an EP1/EP3-dependent mechanism. J. Immunol. 165, 6545-6552.

Gruber, B. L., Marchese, M. J., and Kew, R. R. (1994). Transforming growth factor- $\beta 1$ mediates mast cell chemotaxis. J. Immunol. 152, 5860-5867.

Haddon, D. J., Antignano, F., Hughes, M. R., Blanchet, M. R., Zbytnuik, L., Krystal, G., and McNagny, K. M. (2009). SHIP1 is a repressor of mast cell hyperplasia, cytokine production, and allergic inflammation in vivo. J. Immunol. 183, 228-236.

Hájková, Z., Bugajev, V., Dráberová, E., Vinopal, S., Dráberová, L., Janáček, J., Dráber, P., and Dráber, P. (2011). STIM1-directed reorganization of microtubules in activated mast cells. J. Immunol. 186, 913-923.

Hallgren, J., and Gurish, M. F. (2007). Pathways of murine mast cell 
development and trafficking: tracking the roots and routes of the mast cell. Immunol. Rev. 217, 8-18.

Hallgren, J., and Gurish, M. F. (2011). Mast cell progenitor trafficking and maturation. Adv. Exp. Med. Biol. 716, 14-28.

Hallgren, J., Jones, T. G., Abonia, J. P., Xing, W., Humbles, A., Austen, K. F., and Gurish, M. F. (2007). Pulmonary CXCR2 regulates VCAM1 and antigen-induced recruitment of mast cell progenitors. Proc. Natl. Acad. Sci. U.S.A. 104, 20478-20483.

Hammad, H., de Heer, H. J., Soullie, T., Hoogsteden, H. C., Trottein, F., and Lambrecht, B. N. (2003). Prostaglandin D2 inhibits airway dendritic cell migration and function in steady state conditions by selective activation of the $\mathrm{D}$ prostanoid receptor 1. J. Immunol. 171, 3936-3940.

Hartmann, K., Henz, B. M., KrugerKrasagakes, S., Kohl, J., Burger, R., Guhl, S., Haase, I., Lippert, U., and Zuberbier, T. (1997). C3a and C5a stimulate chemotaxis of human mast cells. Blood 89, 2863-2870.

Heit, B., Liu, L., Colarusso, P., Puri, K. D., and Kubes, P. (2008). PI3K accelerates, but is not required for, neutrophil chemotaxis to fMLP. J. Cell Sci. 121, 205-214.

Heit, B., Tavener, S., Raharjo, E., and Kubes, P. (2002). An intracellular signaling hierarchy determines direction of migration in opposing chemotactic gradients. J. Cell Biol. 159, 91-102.

Hirai, H., Tanaka, K., Yoshie, O., Ogawa, K., Kenmotsu, K., Takamori, Y., Ichimasa, M., Sugamura, K., Nakamura, M., Takano, S., and Nagata, K. (2001). Prostaglandin D2 selectively induces chemotaxis in $\mathrm{T}$ helper type 2 cells, eosinophils, and basophils via seven-transmembrane receptor CRTH2. J. Exp. Med. 193, 255-261.

Huang, Y. E., Iijima, M., Parent, C. A., Funamoto, S., Firtel, R. A., and Devreotes, P. (2003). Receptormediated regulation of PI3Ks confines $\mathrm{PI}(3,4,5) \mathrm{P} 3$ to the leading edge of chemotaxing cells. Mol. Biol. Cell 14, 1913-1922.

Humbles, A. A., Lu, B., Friend, D. S., Okinaga, S., Lora, J., Al-Garawi, A., Martin, T. R., Gerard, N. P., and Gerard, C. (2002). The murine CCR3 receptor regulates both the role of eosinophils and mast cells in allergen-induced airway inflammation and hyperresponsiveness. Proc. Natl. Acad. Sci. U.S.A 99, 1479-1484.

Ichikawa, A., Sugimoto, Y., and Negishi, M. (1996). Molecular aspects of the structures and functions of the prostaglandin E receptors. J. Lipid Mediat. Cell Signal. 14, 83-87.

Iijima, M., Huang, Y. E., and Devreotes, P. (2002). Temporal and spatial regulation of chemotaxis. Dev. Cell 3, 469-478.

Iijima, M., Huang, Y. E., Luo, H. R., Vazquez, F., and Devreotes, P. N. (2004). Novel mechanism of PTEN regulation by its phosphatidylinositol 4,5-bisphosphate binding motif is critical for chemotaxis. J. Biol. Chem. 279, 16606-16613.

Inamura, H., Kurosawa, M., Okano, A., Kayaba, H., and Majima, M. (2002). Expression of the interleukin-8 receptors CXCR1 and CXCR2 on cord-blood-derived cultured human mast cells. Int. Arch. Allergy Immunol. 128, 142-150.

Insall, R. H. (2010). Understanding eukaryotic chemotaxis: a pseudopod-centred view. Nat. Rev. Mol. Cell Biol. 11, 453-458.

Ishiai, M., Kurosaki, M., Inabe, K., Chan, A. C., Sugamura, K., and Kurosaki, T. (2000). Involvement of LAT, Gads, and Grb2 in compartmentation of SLP-76 to the plasma membrane. J. Exp. Med. 192, 847-856.

Ishizuka, T., Okajima, F., Ishiwara, M., Iizuka, K., Ichimonji, I., Kawata, T., Tsukagoshi, H., Dobashi, K., Nakazawa, T., and Mori, M. (2001). Sensitized mast cells migrate toward the antigen: a response regulated by p 38 mitogenactivated protein kinase and Rho-associated coiled-coil-forming protein kinase. J. Immunol. 167, 2298-2304.

Janssen, E., Zhu, M., Zhang, W., Koonpaew, S., and Zhang, W. (2003). LAB: a new membrane-associated adaptor molecule in B cell activation. Nat. Immunol. 4, 117-123.

Jensen, B. M., Beaven, M. A., Iwaki, S., Metcalfe, D. D., and Gilfillan, A. M. (2008). Concurrent inhibition of kit- and FceRI-mediated signaling: coordinated suppression of mast cell activation. J. Pharmacol. Exp. Ther. 324, 128-138.

Jiang, Y., Borrelli, L. A., Kanaoka, Y., Bacskai, B. J., and Boyce, J. A. (2007). CysLT2 receptors interact with CysLT1 receptors and downmodulate cysteinyl leukotriene dependent mitogenic responses of mast cells. Blood 110, 3263-3270.

Jiang, Y., Kanaoka, Y., Feng, C., Nocka, K., Rao, S., and Boyce, J. A. (2006). Cutting edge: Interleukin 4dependent mast cell proliferation requires autocrine/intracrine cysteinyl leukotriene-induced signaling. J. Immunol. 177, 2755-2759.
Jolly, P. S., Bektas, M., Olivera, A., Gonzalez-Espinosa, C., Proia, R. L., Rivera, J., Milstien, S., and Spiegel, S. (2004). Transactivation of sphingosine-1-phosphate receptors by FceRI triggering is required for normal mast cell degranulation and chemotaxis. J. Exp. Med. 199, 959-970.

Jolly, P. S., Bektas, M., Watterson, K. R. Sankala, H., Payne, S. G., Milstien, S., and Spiegel, S. (2005). Expression of SphK1 impairs degranulation and motility of RBL-2H3 mast cells by desensitizing S1P receptors. Blood 105, 4736-4742.

Juremalm, M., Hjertson, M., Olsson, N., Harvima, I., Nilsson, K., and Nilsson, G. (2000). The chemokine receptor CXCR4 is expressed within the mast cell lineage and its ligand stromal cell-derived factor- $1 \alpha$ acts as a mast cell chemotaxin. Eur. J. Immunol. 30 3614-3622.

Juremalm, M., and Nilsson, G. (2005) Chemokine receptor expression by mast cells. Chem. Immunol. Allergy 87, 130-144.

Juremalm, M., Olsson, N., and Nilsson, G. (2002). Selective CCL5/RANTESinduced mast cell migration through interactions with chemokine receptors CCR1 and CCR4. Biochem. Biophys. Res. Commun. 297, 480-485.

Kanegasaki, S., Nomura, Y., Nitta, N., Akiyama, S., Tamatani, T., Goshoh, Y., Yoshida, T., Sato, T., and Kikuchi, Y. (2003). A novel optical assay system for the quantitative measurement of chemotaxis. J. Immunol. Methods 282, 1-11.

Kaplan, A. P. (2001). Chemokines, chemokine receptors and allergy. Int. Arch. Allergy Immunol. 124, 423-431.

Kay, L. J., Yeo, W. W., and Peachell, P. T. (2006). Prostaglandin E2 activates $\mathrm{EP} 2$ receptors to inhibit human lung mast cell degranulation. $\mathrm{Br}$. J. Pharmacol. 147, 707-713.

Kay, R. R., Langridge, P., Traynor, D. and Hoeller, O. (2008). Changing directions in the study of chemotaxis. Nat. Rev. Mol. Cell Biol. 9, 455-463.

Kim, M. S., Kuehn, H. S., Metcalfe, D. D. and Gilfillan, A. M. (2008a). Activation and function of the mTORC1 pathway in mast cells. J. Immunol. 180, 4586-4595.

Kim, M. S., Rådinger, M., and Gilfillan, A. M. (2008b). The multiple roles of phosphoinositide 3-kinase in mast cell biology. Trends Immunol. 29, 493-501.

Kitaura, J., Eto, K., Kinoshita, T., Kawakami, Y., Leitges, M., Lowell, C.
A., and Kawakami, T. (2005a). Regulation of highly cytokinergic IgEinduced mast cell adhesion by $\mathrm{Src}$, Syk, Tec, and protein kinase C family kinases. J. Immunol. 174, 4495-4504.

Kitaura, J., Kinoshita, T., Matsumoto, M., Chung, S., Kawakami, Y., Leitges, M., Wu, D., Lowell, C. A., and Kawakami, T. (2005b). IgE- and IgE + Ag-mediated mast cell migration in an autocrine/paracrine fashion. Blood 105, 32223229.

Kolsch, V., Charest, P. G., and Firtel, R. A. (2008). The regulation of cell motility and chemotaxis by phospholipid signaling. J. Cell Sci. 121, 551-559.

Kortholt, A., Kataria, R., KeizerGunnink, I., van Egmond, W. N., Khanna, A., and van Haastert, P. J. (2011). Dictyostelium chemotaxis: essential Ras activation and accessory signalling pathways for amplification. EMBO Rep. 12, 1273-1279.

Kramer, R. M., and Sharp, J. D. (1995). Recent insights into the structure, function and biology of CPLA2. Agents Actions Suppl. 46, 65-76.

Kramer, R. M., and Sharp, J. D. (1997) Structure, function and regulation of $\mathrm{Ca}^{2+}$-sensitive cytosolic phospholipase A2 (cPLA2). FEBS Lett. 410, 49-53.

Kuehn, H. S., and Gilfillan, A. M. (2007). $G$ protein-coupled receptors and the modification of FceRI-mediated mast cell activation. Immunol. Lett. 113, 59-69.

Kuehn, H. S., Jung, M. Y., Beaven, M. A., Metcalfe, D. D., and Gilfillan, A. M. (2011a). Distinct PGE2responder and non-responder phenotypes in human mast cell populations: "all or nothing" enhancement of antigen-dependent mediator release. Immunol. Lett. 141, 45-54.

Kuehn, H. S., Jung, M. Y., Beaven, M. A., Metcalfe, D. D., and Gilfillan, A. M. (2011b). Prostaglandin E2 activates and utilizes mTORC2 as a central signaling locus for the regulation of mast cell chemotaxis and mediator release. J. Biol. Chem. 286, 391-402.

Kuehn, H. S., Rådinger, M., Brown, J. M., Ali, K., Vanhaesebroeck, B., Beaven, M. A., Metcalfe, D. D., and Gilfillan, A. M. (2010). Btk-dependent Rac activation and actin rearrangement following FceRI aggregation promotes enhanced chemotactic responses of mast cells. J. Cell Sci. 123, 2576-2585.

Kuehn, H. S., Swindle, E. J., Kim, M. S., Beaven, M. A., Metcalfe, D. D., and Gilfillan, A. M. (2008). The phosphoinositide 3-kinase-dependent 
activation of Btk is required for optimal eicosanoid production and generation of reactive oxygen species in antigen-stimulated mast cells. J. Immunol. 181, 7706-7712.

Kushnir-Sukhov, N. M., Gilfillan, A. M., Coleman, J. W., Brown, J. M., Bruening, S., Toth, M., and Metcalfe, D. D. (2006). 5-hydroxytryptamine induces mast cell adhesion and migration. J. Immunol. 177, 6422-6432.

Lee, S., Comer, F. I., Sasaki, A., McLeod, I. X., Duong, Y., Okumura, K., Yates, J. R. III, Parent, C. A., and Firtel, R. A. (2005). TOR complex 2 integrates cell movement during chemotaxis and signal relay in Dictyostelium. Mol. Biol. Cell 16, 4572-4583.

Lewis, R. A., Soter, N. A., Diamond, P. T., Austen, K. F., Oates, J. A., and Roberts, L. J. (1982). Prostaglandin D2 generation after activation of rat and human mast cells with anti-IgE. J. Immunol. 129, 1627-1631.

Linnekin, D., DeBerry, C. S., and Mou, S. (1997). Lyn associates with the juxtamembrane region of c-Kit and is activated by stem cell factor in hematopoietic cell lines and normal progenitor cells. J. Biol. Chem. 272, 27450-27455.

Liou, J., Kim, M. L., Heo, W. D., Jones, J. T., Myers, J. W., Ferrell, J. E. Jr., and Meyer, T. (2005). STIM is a $\mathrm{Ca}^{2+}$ sensor essential for $\mathrm{Ca}^{2+}$-store-depletion-triggered $\mathrm{Ca}^{2+}$ influx. Curr. Biol. 15, 1235-1241.

Liu, H., Toman, R. E., Goparaju, S. K., Maceyka, M., Nava, V. E., Sankala, H., Payne, S. G., Bektas, M., Ishii, I., Chun, J., Milstien, S., and Spiegel, S. (2003). Sphingosine kinase type 2 is a putative $\mathrm{BH} 3$-only protein that induces apoptosis. J. Biol. Chem. 278, 40330-40336.

Liu, L., Das, S., Losert, W., and Parent, C. A. (2010). mTORC2 regulates neutrophil chemotaxis in a cAMP- and RhoA-dependent fashion. Dev. Cell 19, 845-857.

Liu, L., and Parent, C. A. (2011). Review series: TOR kinase complexes and cell migration. J. Cell Biol. 194, 815-824.

Liu, S. K., Fang, N., Koretzky, G. A., and McGlade, C. J. (1999). The hematopoietic-specific adaptor protein gads functions in T-cell signaling via interactions with the SLP76 and LAT adaptors. Curr. Biol. 9, 67-75.

Lloyd, C. M., and Brown, Z. (2006). Chemokine receptors: therapeutic potential in asthma. Treat. Respir. Med. 5, 159-166.
Loovers, H. M., Postma, M., KeizerGunnink, I., Huang, Y. E., Devreotes, P. N., and van Haastert, P. J. (2006). Distinct roles of PI $(3,4,5) \mathrm{P} 3$ during chemoattractant signaling in Dictyostelium: a quantitative in vivo analysis by inhibition of PI3-kinase. Mol. Biol. Cell 17, 1503-1513.

Lundeen, K. A., Sun, B., Karlsson, L., and Fourie, A. M. (2006). Leukotriene B4 receptors BLT1 and BLT2: expression and function in human and murine mast cells. J. Immunol. 177, 3439-3447.

Mathes, C., Fleig, A., and Penner, R. (1998). Calcium release-activated calcium current (ICRAC) is a direct target for sphingosine. J. Biol. Chem. 273, 25020-25030.

Matsui, K., and Nishikawa, A. (2005). Percutaneous application of peptidoglycan from Staphylococcus aureus induces an increase in mast cell numbers in the dermis of mice. Clin. Exp. Allergy 35, 382-387.

McCloskey, M. A., Fan, Y., and Luther, S. (1999). Chemotaxis of rat mast cells toward adenine nucleotides. $J$. Immunol. 163, 970-977.

Meininger, C. J., Yano, H., Rottapel, R., Bernstein, A., Zsebo, K. M., and Zetter, B. R. (1992). The c-kit receptor ligand functions as a mast cell chemoattractant. Blood 79, 958-963.

Melendez, A. J., and Khaw, A. K. (2002). Dichotomy of $\mathrm{Ca}^{2+}$ signals triggered by different phospholipid pathways in antigen stimulation of human mast cells. J. Biol. Chem. 277, 17255-17262.

Mellor, E. A., Frank, N., Soler, D., Hodge, M. R., Lora, J. M., Austen, K. F., and Boyce, J. A. (2003). Expression of the type 2 receptor for cysteinyl leukotrienes (CysLT2R) by human mast cells: functional distinction from CysLT1R. Proc. Natl. Acad. Sci. U.S.A. 100, 11589-11593.

Misiak-Tloczek, A., and BrzezińskaBlaszczyk, E. (2009). IL-6, but not IL-4, stimulates chemokinesis and TNF stimulates chemotaxis of tissue mast cells: involvement of both mitogen-activated protein kinases and phosphatidylinositol 3-kinase signalling pathways. APMIS 117, 558-567.

Mizugishi, K., Yamashita, T., Olivera, A., Miller, G. F., Spiegel, S., and Proia, R. L. (2005). Essential role for sphingosine kinases in neural and vascular development. Mol. Cell Biol. 25, 11113-11121.

Möhle, R., Bautz, F., Denzlinger, C., and Kanz, L. (2001). Transendothelial migration of hematopoietic progenitor cells. Role of chemotactic factors. Ann. N. Y. Acad. Sci. 938, 26-34.
Narumiya, S., and Watanabe, N. (2009). Migration without a clutch. Nat. Cell Biol. 11, 1394-1396.

Nataraj, C., Thomas, D. W., Tilley, S. L., Nguyen, M. T., Mannon, R., Koller, B. H., and Coffman, T. M. (2001). Receptors for prostaglandin E2 that regulate cellular immune responses in the mouse. J. Clin. Invest. 108, 1229-1235.

Nguyen, J. T., Porter, M., Amoui, M., Miller, W. T., Zuckermann, R. N. and Lim, W. A. (2000). Improving SH3 domain ligand selectivity using a non-natural scaffold. Chem. Biol. 7, 463-473.

Nilsson, G., Butterfield, J. H., Nilsson, K., and Siegbahn, A. (1994). Stem cell factor is a chemotactic factor for human mast cells. J. Immunol. 153, 3717-3723.

Nilsson, G., Hjertson, M., Andersson, M., Greiff, L., Svensson, C., Nilsson, K., and Siegbahn, A. (1998). Demonstration of mast-cell chemotactic activity in nasal lavage fluid: characterization of one chemotaxin as c-kit ligand, stem cell factor. Allergy 53, 874-879.

Nilsson, G., Johnell, M., Hammer, C. H., Tiffany, H. L., Nilsson, K., Metcalfe, D. D., Siegbahn, A., and Murphy, P. M. (1996). C3a and C5a are chemotaxins for human mast cells and act through distinct receptors via a pertussis toxin-sensitive signal transduction pathway. J. Immunol. 157, 1693-1698.

Nilsson, G., Metcalfe, D. D., and Taub, D. D. (2000). Demonstration that platelet-activating factor is capable of activating mast cells and inducing a chemotactic response. Immunology 99, 314-319.

Nishio, M., Watanabe, K., Sasaki, J., Taya, C., Takasuga, S., Iizuka, R., Balla, T., Yamazaki, M., Watanabe, H., Itoh, R., Kuroda, S., Horie, Y., Forster, I., Mak, T. W., Yonekawa, H., Penninger, J. M., Kanaho, Y., Suzuki, A., and Sasaki, T. (2007). Control of cell polarity and motility by the PtdIns $(3,4,5) \mathrm{P} 3$ phosphatase SHIP1. Nat. Cell Biol. 9, 36-44.

Ochi, H., Hirani, W. M., Yuan, Q., Friend, D. S., Austen, K. F., and Boyce, J. A. (1999). T helper cell type 2 cytokine-mediated comitogenic responses and CCR 3 expression during differentiation of human mast cells in vitro. J. Exp. Med. 190, 267-280.

Ohnishi, H., Miyahara, N., and Gelfand, E. W. (2008). The role of leukotriene B4 in allergic diseases. Allergol. Int. 57, 291-298.

Okayama, Y., and Kawakami, T. (2006) Development, migration, and survival of mast cells. Immunol. Res. 34, 97-115.

Oliveira, S. H., and Lukacs, N. W. (2001). Stem cell factor and IgEstimulated murine mast cells produce chemokines (CCL2, CCL17, CCL22) and express chemokine receptors. Inflamm. Res. 50, 168-174.

Olivera, A. (2008). Unraveling the complexities of sphingosine-1phosphate function: the mast cell model. Prostaglandins Other Lipid Mediat. 86, 1-11.

Olivera, A., Kohama, T., Edsall, L., Nava, V., Cuvillier, O., Poulton, S., and Spiegel, S. (1999). Sphingosine kinase expression increases intracellular sphingosine-1-phosphate and promotes cell growth and survival. J. Cell Biol. 147, 545-558.

Olivera, A., Mizugishi, K., Tikhonova, A., Ciaccia, L., Odom, S., Proia, R. L., and Rivera, J. (2007). The sphingosine kinase-sphingosine-1phosphate axis is a determinant of mast cell function and anaphylaxis. Immunity 26, 287-297.

Olivera, A., and Rivera, J. (2005). Sphingolipids and the balancing of immune cell function: lessons from the mast cell. J. Immunol. 174, 1153-1158.

Olivera, A., and Spiegel, S. (2001). Sphingosine kinase: a mediator of vital cellular functions. Prostaglandins 64, 123-134.

Olivera, A., Urtz, N., Mizugishi, K., Yamashita, Y., Gilfillan, A. M., Furumoto, Y., Gu, H., Proia, R. L., Baumruker, T., and Rivera, J. (2006). IgEdependent activation of sphingosine kinases 1 and 2 and secretion of sphingosine 1-phosphate requires Fyn kinase and contributes to mast cell responses. J. Biol. Chem. 281, 2515-2525.

Olsson, N., Rak, S., and Nilsson, G. (2000). Demonstration of mast cell chemotactic activity in bronchoalveolar lavage fluid collected from asthmatic patients before and during pollen season. J. Allergy Clin. Immunol. 105, 455-461.

Osher, E., Weisinger, G., Limor, R., Tordjman, K., and Stern, N. (2006). The 5 lipoxygenase system in the vasculature: emerging role in health and disease. Mol. Cell Endocrinol. 252, 201-206.

Oskeritzian, C. A., Alvarez, S. E., Hait, N. C., Price, M. M., Milstien, S., and Spiegel, S. (2008). Distinct roles of sphingosine kinases 1 and 2 in human mast-cell functions. Blood 111, 4193-4200.

Papadopoulos, E. J., Fitzhugh, D. J., Tkaczyk, C., Gilfillan, A. M., 
Sassetti, C., Metcalfe, D. D., and Hwang, S. T. (2000). Mast cells migrate, but do not degranulate, in response to fractalkine, a membrane-bound chemokine expressed constitutively in diverse cells of the skin. Eur. J. Immunol. 30, 2355-2361.

Papakonstanti, E. A., Ridley, A. J., and Vanhaesebroeck, B. (2007). The p1108 isoform of PI 3-kinase negatively controls RhoA and PTEN. EMBO J. 26, 3050-3061.

Parravicini, V., Gadina, M., Kovarova, M., Odom, S., Gonzalez-Espinosa, C., Furumoto, Y., Saitoh, S., Samelson, L. E., O'Shea, J. J., and Rivera, J. (2002). Fyn kinase initiates complementary signals required for IgE-dependent mast cell degranulation. Nat. Immunol. 3 , 741-748.

Peest, U., Sensken, S. C., Andreani, P., Hanel, P., Van Veldhoven, P. P., and Graler, M. H. (2008). S1P-lyase independent clearance of extracellular sphingosine 1-phosphate after dephosphorylation and cellular uptake. J. Cell Biochem. 104, 756-772.

Pietrzak, A., Wierzbicki, M., Wiktorska, M., and Brzezinska-Blaszczyk, E. (2011). Surface TLR2 and TLR4 expression on mature rat mast cells can be affected by some bacterial components and proinflammatory cytokines. Mediators Inflamm. 2011, 427473.

Poole, T. J., and Zetter, B. R. (1983). Stimulation of rat peritoneal mast cell migration by tumor-derived peptides. Cancer Res. 43, 58575861.

Ralevic, V., and Burnstock, G. (1998). Receptors for purines and pyrimidines. Pharmacol. Rev. 50, 413-492.

Ramkumar, V., Stiles, G. L., Beaven, M. A., and Ali, H. (1993). The A3 adenosine receptor is the unique adenosine receptor which facilitates release of allergic mediators in mast cells. $J$. Biol. Chem. 268, 16887-16890.

Razin, E., Cordon-Cardo, C., and Good, R. A. (1981). Growth of a pure population of mouse mast cells in vitro with conditioned medium derived from concanavalin A-stimulated splenocytes. Proc. Natl. Acad. Sci. U.S.A. 78, 2559-2561.

Razin, E., Mencia-Huerta, J. M., Stevens, R. L., Lewis, R. A., Liu, F. T., Corey, E., and Austen, K. F. (1983). IgEmediated release of leukotriene $\mathrm{C} 4$, chondroitin sulfate E proteoglycan, $\beta$-hexosaminidase, and histamine from cultured bone marrow-derived mouse mast cells. J. Exp. Med. 157, 189-201.

Renkawitz, J., Schumann, K., Weber, M., Lämmermann, T., Pflicke, H., Piel, M., Polleux, J., Spatz, J. P., and Sixt, M. (2009). Adaptive force transmission in amoeboid cell migration. Nat. Cell Biol. 11, 1438-1443.

Rivera, J., Proia, R. L., and Olivera, A. (2008). The alliance of sphingosine1-phosphate and its receptors in immunity. Nat. Rev. Immunol. 8, 753-763.

Romagnani, P., de Paulis, A., Beltrame, C., Annunziato, F., Dente, V., Maggi, E., Romagnani, S., and Marone, G. (1999). Tryptase-chymase doublepositive human mast cells express the eotaxin receptor CCR3 and are attracted by CCR3-binding chemokines. Am. J. Pathol. 155, 1195-1204.

Romagnani, S. (2002). Cytokines and chemoattractants in allergic inflammation. Mol. Immunol. 38, 881-885.

Roos, J., DiGregorio, P. J., Yeromin, A. V., Ohlsen, K., Lioudyno, M., Zhang, S., Safrina, O., Kozak, J. A., Wagner, S. L., Cahalan, M. D., Velicelebi, G., and Stauderman, K. A. (2005). STIM1, an essential and conserved component of store-operated $\mathrm{Ca}^{2+}$ channel function. J. Cell Biol. 169, 435-445.

Roskoski, R. Jr. (2005). Signaling by Kit protein-tyrosine kinase-the stem cell factor receptor. Biochem. Biophys. Res. Commun. 337, 1-13.

Ruschpler, P., Lorenz, P., Eichler, W., Koczan, D., Hanel, C., Scholz, R., Melzer, C., Thiesen, H. J., and Stiehl, P. (2003). High CXCR3 expression in synovial mast cells associated with CXCL9 and CXCL10 expression in inflammatory synovial tissues of patients with rheumatoid arthritis. Arthritis Res. Ther. 5, R241R252.

Sabroe, I., Lloyd, C. M., Whyte, M. K., Dower, S. K., Williams, T. J., and Pease, J. E. (2002). Chemokines, innate and adaptive immunity, and respiratory disease. Eur. Respir. J. 19, 350-355.

Saito, H., Kato, A., Matsumoto, K., and Okayama, Y. (2006). Culture of human mast cells from peripheral blood progenitors. Nat. Protoc. 1, 2178-2183.

Samayawardhena, L. A., Hu, J., Stein, P. L., and Craig, A. W. (2006). Fyn kinase acts upstream of Shp2 and p38 mitogen-activated protein kinase to promote chemotaxis of mast cells towards stem cell factor. Cell. Signal. 18, 1447-1454.

Samayawardhena, L. A., Kapur, R., and Craig, A. W. (2007). Involvement of Fyn kinase in Kit and integrinmediated Rac activation, cytoskeletal reorganization, and chemotaxis of mast cells. Blood 109, 3679-3686.

Samayawardhena, L. A., and Pallen, C. J. (2008). Protein-tyrosine phosphatase $\alpha$ regulates stem cell factordependent $\mathrm{c}$-Kit activation and migration of mast cells. J. Biol. Chem. 283, 29175-29185.

Sasaki, A. T., and Firtel, R. A. (2006). Regulation of chemotaxis by the orchestrated activation of Ras, PI3K and TOR. Eur. J. Cell Biol. 85, 873-895.

Sawada, J., Shimizu, S., Tamatani, T., Kanegasaki, S., Saito, H., Tanaka, A., Kambe, N., Nakahata, T., and Matsuda, H. (2005). Stem cell factor has a suppressive activity to IgEmediated chemotaxis of mast cells. J. Immunol. 174, 3626-3632.

Schwab, S. R., Pereira, J. P., Matloubian, M., Xu, Y., Huang, Y., and Cyster J. G. (2005). Lymphocyte sequestration through S1P lyase inhibition and disruption of S1P gradients. Science 309, 1735-1739.

Scott, K., and Bradding, P. (2005). Human mast cell chemokines receptors: implications for mast cell tissue localization in asthma. Clin. Exp. Allergy 35, 693-697.

Shiraishi, Y., Asano, K., Nakajima, T., Oguma, T., Suzuki, Y., Shiomi, T., Sayama, K., Niimi, K., Wakaki, M., Kagyo, J., Ikeda, E., Hirai, H., Yamaguchi, K., and Ishizaka, A. (2005). Prostaglandin D2-induced eosinophilic airway inflammation is mediated by CRTH2 receptor. $J$. Pharmacol. Exp. Ther. 312, 954-960.

Sieh, M., Batzer, A., Schlessinger, J., and Weiss, A. (1994). GRB2 and phospholipase C- $\gamma 1$ associate with a 36- to 38-kilodalton phosphotyrosine protein after T-cell receptor stimulation. Mol. Cell Biol. 14, 4435-4442.

Smith, J. A., Samayawardhena, L. A., and Craig, A. W. (2010). Fps/Fes proteintyrosine kinase regulates mast cell adhesion and migration downstream of Kit and $\beta 1$ integrin receptors. Cell. Signal. 22, 427-436.

Subramanian, K. K., Jia, Y., Zhu, D. Simms, B. T., Jo, H., Hattori, H., You, J., Mizgerd, J. P., and Luo, H. R. (2007). Tumor suppressor PTEN is a physiologic suppressor of chemoattractant-mediated neutrophil functions. Blood 109, 4028-4037.

Sullivan, R., Price, L. S., and Koffer, A. (1999). Rho controls cortical F-actin disassembly in addition to, but independently of, secretion in mast cells. J. Biol. Chem. 274, 38140-38146.

Takeda, K., Sasaki, A. T., Ha, H., Seung, H. A., and Firtel, R. A. (2007). Role of phosphatidylinositol 3-kinases in chemotaxis in Dictyostelium. J. Biol. Chem. 282, 11874-11884.

Taub, D., Dastych, J., Inamura, N., Upton, J., Kelvin, D., Metcalfe, D., and Oppenheim, J. (1995). Bone marrow-derived murine mast cells migrate, but do not degranulate, in response to chemokines. J. Immunol. 154, 2393-2402.

Taylor, M. L., Dastych, J., Sehgal, D., Sundstrom, M., Nilsson, G., Akin, C., Mage, R. G., and Metcalfe, D. D. (2001). The Kit-activating mutation D816V enhances stem cell factordependent chemotaxis. Blood 98, 1195-1199.

Timokhina, I., Kissel, H., Stella, G. and Besmer, P. (1998). Kit signaling through PI 3-kinase and Src kinase pathways: an essential role for Racl and JNK activation in mast cell proliferation. EMBO J. 17, 6250-6262.

Toda, A., Yokomizo, T., and Shimizu, T. (2002). Leukotriene B4 receptors. Prostaglandins Other Lipid Mediat. 68-69, 575-585.

Toda, M., Dawson, M., Nakamura, T., Munro, P. M., Richardson, R. M., Bailly, M., and Ono, S. J. (2004). Impact of engagement of Fc\&RI and CC chemokine receptor 1 on mast cell activation and motility. J. Biol. Chem. 279, 48443-48448.

Trub, T., Frantz, J. D., Miyazaki, M., Band, H., and Shoelson, S. E. (1997). The role of a lymphoid-restricted, Grb2-like SH3-SH2-SH3 protein in $\mathrm{T}$ cell receptor signaling. J. Biol. Chem. 272, 894-902.

Tsai, M., Takeishi, T., Thompson, H., Langley, K. E., Zsebo, K. M., Metcalfe, D. D., Geissler, E. N., and Galli, S. J. (1991). Induction of mast cell proliferation, maturation, and heparin synthesis by the rat c-kit ligand, stem cell factor. Proc. Natl. Acad. Sci. U.S.A. 88, 6382-6386.

Tủmová, M., Koffer, A., Šimíček, M., Dráberova, L., and Dráber, P. (2010). The transmembrane adaptor protein NTAL signals to mast cell cytoskeleton via the small GTPase Rho. Eur. J. Immunol. 40, 3235-3245.

Ueda, S., Mizuki, M., Ikeda, H., Tsujimura, T., Matsumura, I., Nakano, K., Daino, H., Honda, Z. Z. Sonoyama, J., Shibayama, H., Sugahara, H., Machii, T., and Kanakura, Y. (2002). Critical roles of c-Kit tyrosine residues 567 and 719 in 
stem cell factor-induced chemotaxis: contribution of src family kinase and PI3-kinase on calcium mobilization and cell migration. Blood 99, 3342-3349.

Urtz, N., Olivera, A., Bofill-Cardona, E., Csonga, R., Billich, A., Mechtcheriakova, D., Bornancin, F., Woisetschläger, M., Rivera, J., and Baumruker, T. (2004). Early activation of sphingosine kinase in mast cells and recruitment to Fc\&RI are mediated by its interaction with Lyn kinase. Mol. Cell Biol. 24, 8765-8777.

Volná, P., Lebduška, P., Dráberová, L., Šímová, S., Heneberg, P., Boubelík, M., Bugajev, V., Malissen, B., Wilson, B. S., Hořejší, V., Malissen, M., and Dráber, P. (2004). Negative regulation of mast cell signaling and function by the adaptor LAB/NTAL. J. Exp. Med. 200, 1001-1013.

Wang, D., and Dubois, R. N. (2010). Eicosanoids and cancer. Nat. Rev. Cancer 10, 181-193.

Wang, X. S., and Lau, H. Y. (2006). Prostaglandin E potentiates the immunologically stimulated histamine release from human peripheral blood-derived mast cells through EP1/EP3 receptors. Allergy 61, 503-506.

Wang, Y., Chen, C. L., and Iijima, M. (2011). Signaling mechanisms for chemotaxis. Dev. Growth Differ. 53, 495-502.
Weller, C. L., Collington, S. J., Brown, J. K., Miller, H. R., Al-Kashi, A. Clark, P., Jose, P. J., Hartnell, A., and Williams, T. J. (2005). Leukotriene B4, an activation product of mast cells, is a chemoattractant for their progenitors. J. Exp. Med. 201, 19611971.

Weller, C. L., Collington, S. J., Hartnell, A., Conroy, D. M., Kaise, T., Barker, J. E., Wilson, M. S., Taylor, G. W., Jose, P. J., and Williams, T. J. (2007). Chemotactic action of prostaglandin E2 on mouse mast cells acting via the PGE2 receptor 3. Proc. Natl. Acad. Sci. U.S.A. 104, 11712-11717.

Wrzesinski, S. H., Wan, Y. Y., and Flavell, R. A. (2007). Transforming growth factor- $\beta$ and the immune response: implications for anticancer therapy. Clin. Cancer Res. 13, 5262-5270.

Yamamoto, Y., Otani, S., Hirai, H., Nagata, K., Aritake, K., Urade, Y., Narumiya, S., Yokozeki, H., Nakamura, M., and Satoh, T. (2011). Dual functions of prostaglandin D2 in murine contact hypersensitivity via DP and CRTH2. Am. J. Pathol. 179, 302-314.

Yamashita, T., Mao, S.-Y., and Metzger, H. (1994). Aggregation of the high-affinity $\operatorname{IgE}$ receptor and enhanced activity of p53/p56lyn protein-tyrosine kinase. Proc. Natl. Acad. Sci. U.S.A. 91, 1125111255.
Yokomizo, T. (2011). Leukotriene B4 receptors: novel roles in immunological regulations. $A d v$. Enzyme Regul. 51, 59-64.

Yokomizo, T., Izumi, T., Chang, K., Takuwa, Y., and Shimizu, T. (1997). A G-protein-coupled receptor for leukotriene B4 that mediates chemotaxis. Nature 387, 620-624.

Yokomizo, T., Kato, K., Terawaki, K., Izumi, T., and Shimizu, T. (2000). A second leukotriene B4 receptor, BLT2. A new therapeutic target in inflammation and immunological disorders. J. Exp. Med. 192, 421-432.

Zhang, W., Sloan-Lancaster, J., Kitchen, J., Trible, R. P., and Samelson, L. E. (1998). LAT: the ZAP-70 tyrosine kinase substrate that links $\mathrm{T}$ cell receptor to cellular activation. Cell 92, 83-92.

Zhong, H., Shlykov, S. G., Molina, J. G., Sanborn, B. M., Jacobson, M. A., Tilley, S. L., and Blackburn, M. R. (2003). Activation of murine lung mast cells by the adenosine A3 receptor. J. Immunol. 171, 338-345.

Zhu, M., Liu, Y., Koonpaew, S., Granillo, O., and Zhang, W. (2004). Positive and negative regulation of FceRImediated signaling by adaptor protein LAB/NTAL. J. Exp. Med. 200, 991-1000.

Zlotnik, A., and Yoshie, O. (2000). Chemokines: a new classification system and their role in immunity. Immunity 12, 121-127.

Zudaire, E., Martínez, A., Garayoa, M., Pío, R., Kaur, G., Woolhiser, M. R. Metcalfe, D. D., Hook, W. A., Siraganian, R. P., Guise, T. A., Chirgwin, J. M., and Cuttitta, F. (2006). Adrenomedullin is a cross-talk molecule that regulates tumor and mast cell function during human carcinogenesis. Am. J. Pathol. 168, 280-291.

Conflict of Interest Statement: The authors declare that the research was conducted in the absence of any commercial or financial relationships that could be construed as a potential conflict of interest.

Received: 22 February 2012; accepted: 24 April 2012; published online: 25 May 2012.

Citation: Halova I, Draberova $L$ and Draber P (2012) Mast cell chemotaxis - chemoattractants and signaling pathways. Front. Immun. 3:119. doi: 10.3389/fimmu.2012.00119

This article was submitted to Frontiers in Molecular Innate Immunity, a specialty of Frontiers in Immunology.

Copyright (C) 2012 Halova, Draberova and Draber. This is an open-access article distributed under the terms of the Creative Commons Attribution Non Commercial License, which permits noncommercial use, distribution, and reproduction in other forums, provided the original authors and source are credited. 